\title{
Fischer-Tropsch biofuels production from syngas obtained by supercritical water reforming of the bio-oil aqueous phase
}

\author{
F.J. Campanario, F.J. Gutiérrez Ortiz \\ Departamento de Ingeniería Química y Ambiental, ETS de Ingeniería, Universidad de Sevilla \\ Camino de los Descubrimientos, s/n. 41092 Sevilla, Spain \\ Phone no: + $34954487260 / 68$ \\ Corresponding author email: “Francisco Javier Gutiérrez Ortiz” frajagutor@us.es
}

\begin{abstract}
A new process to produce low-temperature Fischer-Tropsch products from the syngas obtained by supercritical water reforming technology of the bio-oil aqueous phase is developed and analyzed. The process includes four sections: syngas production from supercritical water reforming, syngas upgrading by water-gas-shift and dry reforming reactors as well as pressure swing adsorption systems, Fischer-Tropsch synthesis and products refining and upgrading through a distillation columns train and hydrocracking reactor. The aim is to produce maximum biofuels and electrical power, achieving the overall energy self-sufficiency. The energy scheme also involves cogeneration (e.g., hot water for district heating) and removal of $\mathrm{CO}_{2}$ for sequestration. Process simulations were carried out by Aspen Plus. The effect of the main operating parameters (feed concentration and composition, as well as operating conditions of Fischer-Tropsch reactor) on the process performance (carbon efficiency with or without refining, biofuel and electricity production) was studied by a sensitivity analysis. This way, the optimal conditions were found, so for a feeding of $60 \mathrm{t} / \mathrm{h}$ with a total organic concentration of 35 wt.\%, carbon efficiency with refining is $38.5 \%$ (4.6 t/h biofuel) and $5.3 \mathrm{MWe}$ is generated. The $\mathrm{CO}_{2}$ for sequestration is $0.50 \mathrm{~kg} / \mathrm{kg}$ of organic feeding.
\end{abstract}

\section{Keywords}

Fischer-Tropsch, Supercritical Water, Bio-oil, Syngas, Reforming, Biofuel 


\section{Introduction}

A few main routes make it possible to produce gas and liquid biofuels, such as extraction of vegetable oils, fermentation of sugars to alcohol, or gasification and chemical synthesis. Some recent studies indicate that the use of Fischer-Tropsch (FT) technology for biomass conversion to synthetic hydrocarbons may offer a promising alternative to conventional diesel and gasoline [1-3]. This synthesis was developed in the 1920s as a chemical process to produce hydrocarbons of different length (i.e. light gases, gasoline, jet fuel, diesel and wax fractions) from a mixture of $\mathrm{CO}$ and $\mathrm{H}_{2}$ called syngas.

Hydrocarbon formation in the FT synthesis is comparable to a polymerization mechanism in which the chain initiation involves the adsorption and dissociation of $\mathrm{CO}$ reactant on the catalyst surface. This is followed by hydrogenation of surface carbon atoms to form methylene groups that act as monomer units $\left(-\mathrm{CH}_{2}-\right)$ in the polymerization. Thus, free radical species methylene $\left(\dot{\mathrm{C}} \mathrm{H}_{2}\right)$ react with hydrogen to form a methyl group, which is the chain initiator. Chain propagates by sequential integration of methylene to alkyl groups thus leading to long-chain hydrocarbons. The termination step occurs by reduction or $\beta$-hydride abstraction to produce n-paraffins or $\alpha$-olefins, respectively [4]. The highly exothermic reactions describing the formation of paraffins and olefins from syngas in FT synthesis are represented by reactions (R1) and (R2) [5]:

$$
\begin{aligned}
& \mathrm{n} \mathrm{CO}+(2 \mathrm{n}+1) \mathrm{H}_{2} \leftrightarrow \mathrm{C}_{\mathrm{n}} \mathrm{H}_{2 \mathrm{n}+2}+\mathrm{n} \mathrm{H}_{2} \mathrm{O} \\
& \mathrm{n} \mathrm{CO}+2 \mathrm{n} \mathrm{H}_{2} \leftrightarrow \mathrm{C}_{\mathrm{n}} \mathrm{H}_{2 n}+\mathrm{n} \mathrm{H}_{2} \mathrm{O}
\end{aligned}
$$

Hydrocarbon production in FT synthesis depends on temperature, thus distinguishing high-temperature FT (HTFT) synthesis $\left(300-350{ }^{\circ} \mathrm{C}\right)$, and low-temperature FT (LTFT) synthesis $\left(180-250^{\circ} \mathrm{C}\right)[2]$. HTFT process produces mainly light hydrocarbons (LPG and gasoline) and LTFT produces heavier hydrocarbons (mainly, diesel and wax). The cobalt- 
based catalyst is used on an industrial scale in either fixed-bed reactors (Shell) or slurry reactors (Sasol), but only for low temperature Fischer-Tropsch (LTFT) process, while iron-based catalyst is used for both HTFT and LTFT synthesis processes [4].

Liquid synthetic fuels (with high volumetric energy density) can be transported by the same means as oil and are free of sulfur, nitrogen and aromatics, which are typically found in normal gasoline and diesel. Thus, emissions from internal combustion engines are reduced. Liquid synthetic fuels are receiving much attention as a real alternative to reduce the petroleum dependence of the transportation sector and can be easily obtained from natural gas, coal and biomass gasification. The resulting processes are known as gas to liquid (GTL), carbon solid to liquid (CTL) and biomass to liquid (BTL), respectively [3]. CTL may involve considerable emissions of $\mathrm{CO}_{2}, \mathrm{SO}_{\mathrm{x}}$ and $\mathrm{NO}_{\mathrm{x}}$ and particulate matter, so gas cleaning systems are necessary. Likewise, availability, transportation, handling, storage and low energy density of biomass are obstacles in the development of large scale biomass processing. For these reasons, biomass can be converted into more transportable forms such as liquid bio-oils through fast pyrolysis, which involves thermal decomposition reactions that occur in a few seconds in the absence of oxygen. Liquid biooil has a higher energy density as compared with solid biomass, so those storage space and transportation problems associated with biomass are reduced [6].

By adding water, bio-oil can be separated in a valuable oil phase and in a wasteaqueous phase, which contains organics compounds (20-30 wt.\%) and may be reutilized and valorized. In this case, supercritical water (SCW) reforming is a suitable process because water does not need to be vaporized. Besides, SCW has additional advantages such as a high capability to solubilize gaseous organic molecules. Indeed, SCW reforming is an emerging technology that has being investigated the last years, as shown in our previous works about the valorization of glycerol from biodiesel production [7-11]. 


\section{Aims and scope}

High energy demand along with large capital costs have been the main drawbacks of FT plants, which may call into question the economic viability of the FT process. The first issue is dealt with in this manuscript, and the second one will be treated in a future to optimize the price of biofuels. Thus, in this paper, a new process of synthetic fuels production from the combination of supercritical water reforming (SCWR) of aqueous phase of bio-oil and Fischer-Tropsch synthesis is designed and analyzed, achieving a novel and efficient via of valorization for the waste-aqueous phase of bio-oil. Therefore, liquid carbon from waste to liquid (WTL) is the process considered in this study.

Figure 1 depicts the concept in a simple way using a block flow diagram. Aqueous phase of bio-oil is reformed under supercritical conditions and converted into syngas. Syngas from SCWR process is expanded in a turbine to generate electrical power and upgraded through water-gas shift and dry reforming reactors as well as by two pressure swing adsorption (PSA) systems. This way, the molar flow rate of $\mathrm{H}_{2}$ and $\mathrm{CO}$ in syngas are increased and a desired $\mathrm{H}_{2} / \mathrm{CO}$ ratio is achieved at the inlet of the FT reactor, which includes a loop to recirculate the unreacted syngas, thus increasing the overall conversion of CO into biofuels. A fraction of recycle gas is purged to avoid inert gases accumulation, and FT liquid is separated in different cuts by a distillation train. In addition, high conversion of the LTFT wax can be obtained under mild hydrocracking conditions thanks to the high chemical reactivity of heavy paraffin and the absence of catalysts contaminants like sulfur or nitrogen compounds [12]. Industrially, the operation of LTFT followed by hydrocracking is industrially applied, as in the Shell Middle Distillate Synthesis Process [13]. An external fuel is not needed as a heat source, because the process is designed to be energy self-sufficient by burning the off-gas from different sections. The proposed process is designed to maximize its performance in terms of (1) biofuels production and 
(2) net electrical power generation, as well as (3) cogeneration water and (4) pure $\mathrm{CO}_{2}$ for sequestration.

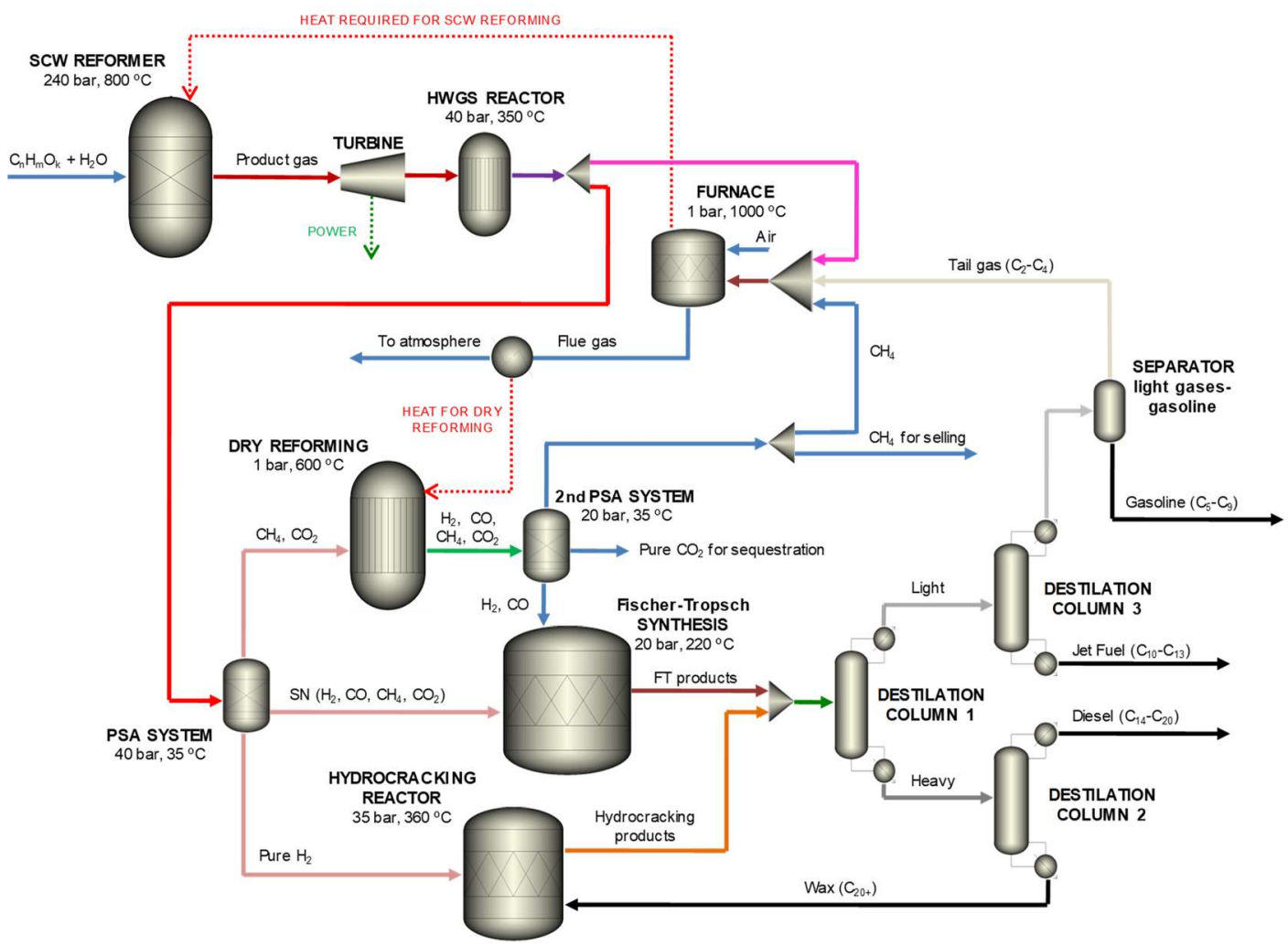

Figure 1. Block flow diagram of the process.

\section{Process design and simulation}

The flowsheet of the SCWR-FT process is illustrated in Figure 2, and specifications of main units are shown in Table 1. The thermal integration is described in Appendix A, where specifications of heat exchangers are also given. The process is divided into four different sections: (1) supercritical water reforming (SCWR) of the bio-oil aqueous fraction, (2) upgrading of the syngas to increase the molar flow rate of $\mathrm{H}_{2}$ and $\mathrm{CO}$ and to achieve the $\mathrm{H}_{2} / \mathrm{CO}$ molar ratio at the FT reactor inlet by water-gas-shift (WGS) and dry reforming (DR) reactors, as well as by two PSA systems, (3) Fischer-Tropsch synthesis loop, and (4) refining and upgrading of FT products through distillation columns and hydrocracking. 


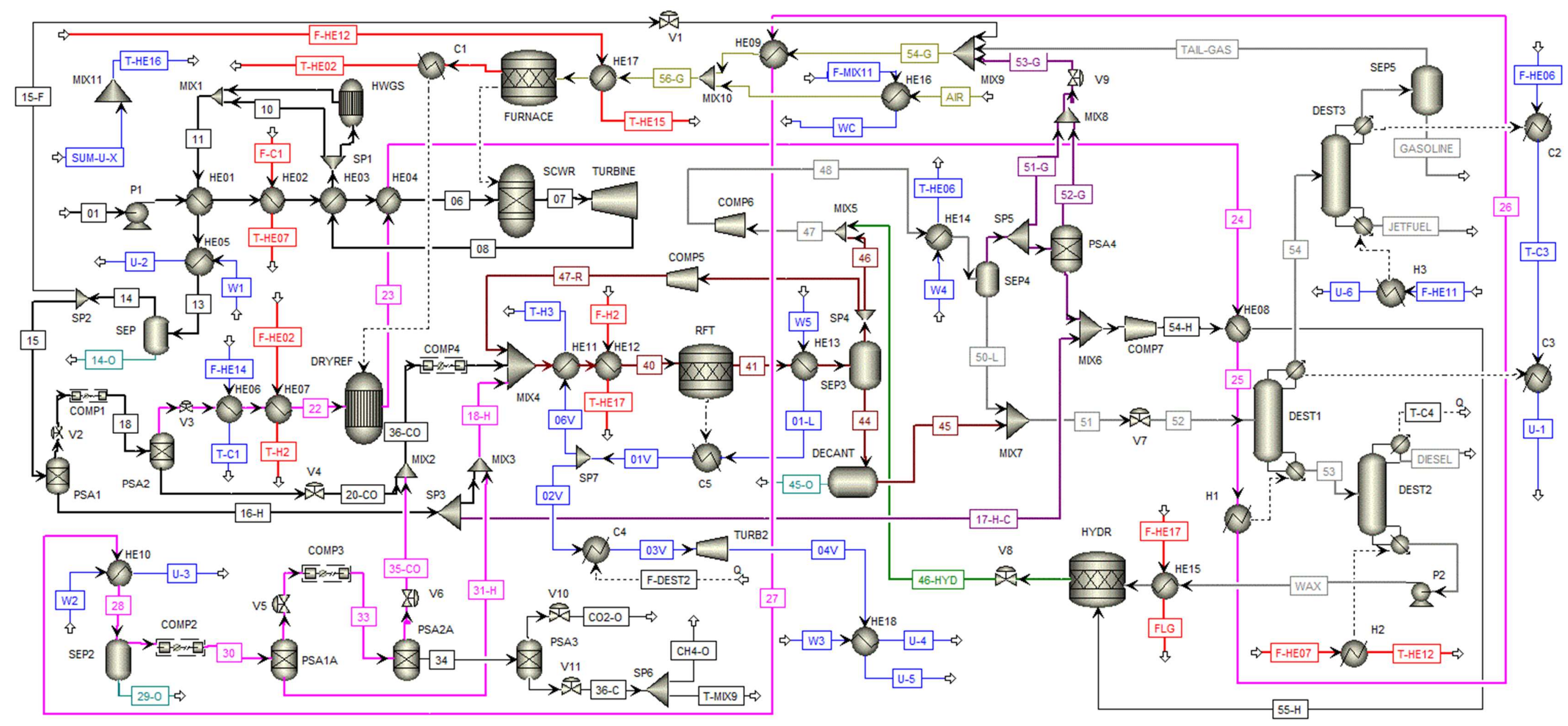

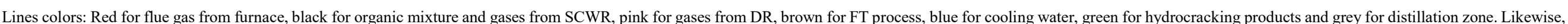

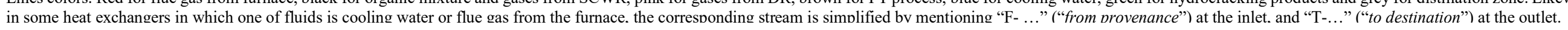

Figure 2. Heat-integrated flowsheet of the SCWR-LTFT process. 
Table 1. Specifications of the main individual process units,

\begin{tabular}{|c|c|c|}
\hline Code & Equipment & Specifications \\
\hline P1 & Pump & Efficiency: 0.8; Outlet pressure: 240 bar \\
\hline SCWR & Supercritical Water Reforming & Operating temperature: $800^{\circ} \mathrm{C}$; Pressure drop: 0.0 bar \\
\hline TURB & Turbine & Type: Isentropic; Efficiency isentropic: 0.85 ; Outlet pressure: variable \\
\hline HWGS & $\begin{array}{l}\text { Water gas-shift reactor, type REquil } \\
\text { (High-temperature stage) }\end{array}$ & $\begin{array}{l}\text { Operating temperature: } 350{ }^{\circ} \mathrm{C} \text {; Pressure drop: } 0.1 \text { bar } \\
\mathrm{CO}+\mathrm{H}_{2} \mathrm{O} \leftrightarrow \mathrm{CO}_{2}+\mathrm{H}_{2}\end{array}$ \\
\hline SEP1-4 & Gas-liquid separators (Flash) & Temperature: $35^{\circ} \mathrm{C}$; Pressure drop: 0.1 bar \\
\hline PSA1 & $\begin{array}{l}\text { Pressure swing adsorption unit } \\
\text { (First PSA system) }\end{array}$ & $\begin{array}{l}\text { It removes most the } \mathrm{H}_{2}(95 \%) \text { from the other gases [15] } \\
\text { Outlet pressure: variable }\left(\mathrm{H}_{2} \text { stream, } 16-\mathrm{H}\right), 1.1 \text { bar (the rest of gases) }\end{array}$ \\
\hline PSA2 & $\begin{array}{l}\text { Pressure swing adsorption unit } \\
\text { (First PSA system) }\end{array}$ & $\begin{array}{l}\text { CO-rich stream: } 98 \% \mathrm{CO}, 1 \% \text { for } \mathrm{CO}_{2} \text { and } \mathrm{CH}_{4}[15] \\
\text { Outlet pressure: } 1.1 \text { bar (top and bottom) }\end{array}$ \\
\hline COMP1 and 3 & $\begin{array}{l}\text { Trains of compression with two } \\
\text { intermediate coolers and one final }\end{array}$ & $\begin{array}{l}\text { Type: Isentropic; Isentropic efficiency: } 0.76 \text {; Mechanical efficiency: } \\
0.98 \text {; intermediate cooling to } 35^{\circ} \mathrm{C} \text {; Outlet pressure: } 15 \text { bar } \\
\text { (compression ratio per stage of } 2.47 \text { ) }\end{array}$ \\
\hline DRYREF & Dry reforming reactor, type REquil & $\begin{array}{l}\text { Isothermal reactor: } 600{ }^{\circ} \mathrm{C} \text {; Operating pressure: } 1.1 \text { bar } \\
\mathrm{CH}_{4}+\mathrm{CO}_{2} \leftrightarrow 2 \mathrm{H}_{2}+2 \mathrm{CO}\end{array}$ \\
\hline PSA1A & $\begin{array}{l}\text { Pressure swing adsorption unit } \\
\text { (Second PSA system) }\end{array}$ & $\begin{array}{l}\text { It removes most the } \mathrm{H}_{2}(95 \%) \text { from the other gases [15] } \\
\text { Outlet pressure: variable }\left(\mathrm{H}_{2} \text { stream, 31-H), } 1.1 \text { bar (the rest of gases) }\right.\end{array}$ \\
\hline PSA2A & $\begin{array}{l}\text { Pressure swing adsorption unit } \\
\text { (Second PSA system) }\end{array}$ & $\begin{array}{l}\mathrm{CO}-\text { rich stream (bottom): } 98 \% \mathrm{CO}, 1 \% \text { for } \mathrm{CO}_{2} \text { and } \mathrm{CH}_{4}[15] \\
\text { Outlet pressure: } 15 \text { bar (34 stream), } 1.1 \text { bar }(35-\mathrm{CO} \text { stream) }\end{array}$ \\
\hline PSA3A & $\begin{array}{l}\text { Pressure swing adsorption unit } \\
\text { (Second PSA system) }\end{array}$ & $\begin{array}{l}\mathrm{CO}_{2} \text {-rich stream (bottom): } 90 \% \mathrm{CO}_{2}, 9 \% \mathrm{CH}_{4}, 0.5 \% \mathrm{CO} \text { and } \mathrm{H}_{2} \\
\text { [15]. Outlet pressure: } 1.1 \text { bar (top and bottom) }\end{array}$ \\
\hline COMP2 and 4 & $\begin{array}{l}\text { Trains of compression with two } \\
\text { intermediate coolers and one final }\end{array}$ & $\begin{array}{l}\text { Type: Isentropic; Isentropic efficiency: } 0.76 \text {; Mechanical efficiency: } \\
0.98 \text {; intermediate cooling to } 35^{\circ} \mathrm{C} \text {; Outlet pressure: variable (but } 3.43 \\
\text { as maximum) }\end{array}$ \\
\hline LTFT & $\begin{array}{l}\text { Low-Temperature Fischer-Tropsch } \\
\text { reactor (RStoic) }\end{array}$ & $\begin{array}{l}\text { Operating temperature: variable }\left(220-240^{\circ} \mathrm{C}\right) \\
\text { Operating pressure: variable }(20-40 \mathrm{bar})\end{array}$ \\
\hline DECANT & Liquid-liquid separator (Decanter) & Temperature: $35^{\circ} \mathrm{C} . ;$ Pressure drop: 0.1 bar \\
\hline COMP5 & Compressor & $\begin{array}{l}\text { Type: Isentropic; Isentropic Efficiency: 0.7; Mechanical efficiency: } \\
0.98 \text {; Outlet pressure: } 20-40 \text { bar }\end{array}$ \\
\hline COMP6 & Compressor & $\begin{array}{l}\text { Type: Isentropic; Isentropic Efficiency: } 0.7 \text {; Mechanical efficiency: } \\
0.98 \text {; Outlet pressure: } 20-35 \text { bar }\end{array}$ \\
\hline PSA4 & Pressure swing adsorption unit & $\begin{array}{l}\text { It removes most the } \mathrm{H}_{2}(95 \%) \text { from the other gases [15] } \\
\text { Outlet pressure: same SEP4 }\end{array}$ \\
\hline DEST1 & Distillation column 1 (heavy-light) & $\begin{array}{l}\text { Operating pressure: } 1.5 \text { bar (reboiler) and } 1.3 \text { bar (condenser) } \\
\text { Reflux ratio: } 1.2 \mathrm{R}_{\min } \\
\mathrm{C}_{13} \mathrm{H}_{28} \text { recovery (distillate stream): } 90 \% \\
\mathrm{C}_{14} \mathrm{H}_{28} \text { recovery (bottom stream): } 99 \%\end{array}$ \\
\hline DEST2 & Distillation column 2 (wax-diesel) & $\begin{array}{l}\text { Operating pressure: } 1.5 \text { bar (reboiler) and } 1.3 \text { bar (condenser) } \\
\text { Reflux ratio: } 1.2 \mathrm{R}_{\min } \\
\mathrm{C}_{20} \mathrm{H}_{42} \text { recovery (distillate stream): } 90 \% \\
\mathrm{C}_{21} \mathrm{H}_{44} \text { recovery (bottom stream): } 90 \%\end{array}$ \\
\hline DEST3 & Distillation column 3 (jet fuel- $\mathrm{C}_{10-}$ ) & $\begin{array}{l}\text { Operating pressure: } 1.3 \text { bar (reboiler) and } 1.2 \text { bar (condenser) } \\
\text { Reflux ratio: } 1.2 \mathrm{R}_{\min } \\
\mathrm{C}_{9} \mathrm{H}_{20} \text { recovery (distillate stream): } 95 \% \\
\mathrm{C}_{10} \mathrm{H}_{20} \text { recovery (bottom stream): } 95 \%\end{array}$ \\
\hline SEP5 & Gas-liquid separator & $\begin{array}{l}\text { Temperature: same that distillate stream in DEST3 } \\
\text { Pressure drop: } 0.1 \text { bar }\end{array}$ \\
\hline COMP7 & Compressor & $\begin{array}{l}\text { Type: Isentropic; Isentropic Efficiency: } 0.75 \text {; Mechanical efficiency: } \\
0.98 \text {; Outlet pressure: } 35 \text { bar }\end{array}$ \\
\hline $\mathrm{P} 2$ & Pump & Efficiency: 0.7; Outlet pressure: 35 bar \\
\hline HYDRCR & Hydrocracking reactor (RStoic) & 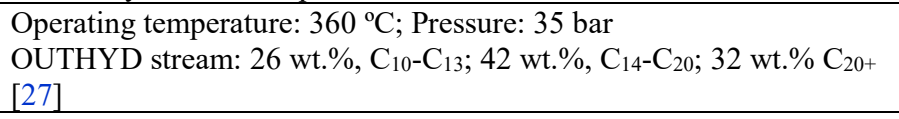 \\
\hline FAN1 & Fan & $\begin{array}{l}\text { Type: Isentropic; Isentropic Efficiency: } 0.76 \text {; Mechanical efficiency: } \\
0.98 \text {; Outlet pressure: } 1.1 \text { bar }\end{array}$ \\
\hline FURNACE & Furnace-combustor (RStoic) & $\begin{array}{l}\text { Combustion of everything able to be oxidized; } 1000^{\circ} \mathrm{C} @ 1 \text { bar } \\
\text { Surplus heat flow to SCWR }\end{array}$ \\
\hline V1-V6, V9-V11 & Valves & Outlet pressure: 1.1 bar \\
\hline V7 & Valve & Outlet pressure: 1.5 bar \\
\hline V8 & Valves & Outlet pressure: variable \\
\hline
\end{tabular}

Note. Specifications of heat exchangers and other auxiliary equipment are given in Appendix A. 


\subsection{Supercritical water reforming of the aqueous fraction of bio-oil}

A mixture of organic compounds representative of the bio-oil aqueous phase is pumped at 240 bar and heated as much as possible by four heat exchangers. The supercritical water reforming (SCWR) reactor operates at 240 bar and $800{ }^{\circ} \mathrm{C}$ to maximize $\mathrm{H}_{2}$ and $\mathrm{CO}$ yields. SCWR reactor is simulated as a Gibbs reactor (RGibbs), where the products yields are calculated under conditions that minimize the Gibbs free energy. This reactor would be located inside of a furnace where a fraction of the product gas from SCWR and WGS reactors, light hydrocarbons gases from distillation section (separator SEP5), unconverted gases from FT synthesis and hydrocracking (PSA4) and the biomethane surplus from dry reforming reactor (PSA3) are burnt to achieve the energy self-sufficiency. The furnace, simulated by a stoichiometric reactor (RStoi), transfers the heat needed by the SCWR reactor, and the flue gas stream leaves the furnace at $1000{ }^{\circ} \mathrm{C}$ to provide heat in other parts of the process. The product gas leaving the supercritical water reformer is expanded by a turbine up to 40 bar to generate electrical power. Thanks to the modern super alloys, the turbines have progressed into the supercritical region, and temperatures and pressures close to those included in this study are currently used, both for steam and gas turbines. However, this is an engineering challenge for this emerging technology, and the gas turbine downstream from the SCW reformer should be specifically designed by considering the gas composition, pressure and temperature and mass flow-rate.

\subsection{Upgrading of the syngas and fit of $\mathrm{H}_{2} / \mathrm{CO}$ molar ratio for FT synthesis}

A fraction of syngas from the turbine outlet enters the high-temperature water-gas shift (HWGS) reactor and the rest by-passes this unit. That fraction is calculated to increase the $\mathrm{H}_{2}$ molar flow rate when the $\mathrm{H}_{2} / \mathrm{CO}$ molar ratio at inlet Fischer-Tropsch reactor is insufficient, which occurs for high organic concentrations of the bio-oil aqueous 
phase (25-35 wt.\%). The high-temperature WGS reaction is moderately exothermic and industrially performed over $\mathrm{Fe}-\mathrm{Cr}$ catalyst for temperature ranging from 350 to $450{ }^{\circ} \mathrm{C}$ [14]. Thus, HWGS reactor operates at $350{ }^{\circ} \mathrm{C}$ and is simulated as an equilibrium reactor (REquil). The gas leaving the HWGS reactor is mixed with the by-pass and cooled to 35 ${ }^{\circ} \mathrm{C}$ in order to condense the steam, which is separated from the gas stream. In this way, the product gas is almost dewatered before its further processing.

The fraction of syngas that is not sent to the furnace is processed by two pressure swing adsorption (PSA) units to obtain a pure $\mathrm{H}_{2}$ stream (at the top of the first PSA unit), as well as a pure $\mathrm{CO}$ stream (at the bottom of the second PSA unit) and a $\mathrm{CO}_{2}+\mathrm{CH}_{4}$-rich stream (at the top of the second PSA unit). Details of these units are described in elsewhere [15]. PSA units are simulated as ideal separators, at $35^{\circ} \mathrm{C}$ and the pressure of syngas. The depressurization steps are simulated by valves, and PSA units are assumed to give a high purity $\mathrm{H}_{2}(99 \%)$ with a hydrogen recovery of $90 \%$ [15], as well as $\mathrm{CO}$ purity higher than $90 \%$ with a CO recovery of $98 \%$. A fraction of the $\mathrm{H}_{2}$-rich stream is sent for hydrocracking and the rest goes to the FT synthesis loop, like the CO-rich stream after recompressing it to the operating pressure of the FT reactor.

The $\mathrm{CH}_{4}$ and $\mathrm{CO}_{2}$ rich stream, with minor $\mathrm{H}_{2}$ and $\mathrm{CO}$ concentrations, is depressurized to 1 bar and heated to $600{ }^{\circ} \mathrm{C}$ before entering the dry reforming (DR) reactor, simulated as REquil. This is a reactor with a nickel-based catalyst where the molar flow rates of CO and $\mathrm{H}_{2}$ increase in a $\mathrm{H}_{2} / \mathrm{CO}$ ratio close to unity, which further justifies the previous WGS stage to achieve the $\mathrm{H}_{2} / \mathrm{CO}$ ratio about 2.0 required for FT synthesis. DR reactor allows the increase in the flow rate of syngas fed into the FT synthesis loop and reduces the $\mathrm{CO}_{2}$ emissions to the atmosphere. However, dry reforming is highly endothermic and temperatures of $600{ }^{\circ} \mathrm{C}$ or higher [16] are necessary to increase the conversion of the reactants and to minimize carbon deposition on the catalyst. Nevertheless, beyond 800 
${ }^{\circ} \mathrm{C}$, the energy required exceed much the gains in $\mathrm{CO}_{2}$ and $\mathrm{CH}_{4}$ conversions, so the temperature of DR reactor was set at $600{ }^{\circ} \mathrm{C}$ to reduce the energy requirement. Likewise, a pressure of 1 bar was used to favor the $\mathrm{CO}$ and $\mathrm{H}_{2}$ production, as pointed by others [17, 18] and verified by simulation by us. Under these operating conditions, $\mathrm{CH}_{4}$ conversion was assumed to be $50 \%$, close to the lower limit of range that may reach $100 \%$ [18].

The humid gas stream leaving the DR reactor is cooled to $35^{\circ} \mathrm{C}$, so the condensate (mainly water) is removed through a separator. Afterwards, the gas is compressed to the operating pressure of Fischer-Tropsch reactor, and enters the second PSA system. As in the first system, PSA1A and PSA2A allow the separation of $\mathrm{H}_{2}$-rich and CO-rich streams that are sent to the inlet of the FT synthesis loop. On the other hand, the $\mathrm{CH}_{4}$ and $\mathrm{CO}_{2}$ rich stream enters PSA3 to obtain a stream of $\mathrm{CO}_{2}$ with a purity higher than $95 \%$ to match the specification for transport and sequestration of $\mathrm{CO}_{2}$ [19], and a $\mathrm{CH}_{4}$-rich stream, which is sent to the furnace or even sold as biomethane if there is energy surplus.

\subsection{Fischer-Tropsch synthesis loop}

$\mathrm{H}_{2}$ and $\mathrm{CO}$ streams, at the operating pressure of the FT reactor, are mixed and heated to the temperature of the FT reactor. In the FT process, the probability of chain growth on the surface of the catalyst $(\alpha)$ is defined by the rate of chain propagation divided by the sum of propagation rates and chain termination. This parameter depends on the reaction conditions and catalyst type, and it is calculated by Eq. (1), obtained by Song et al [20] for cobalt-based catalysts used for LTFT.

$$
\alpha=\left(A \frac{y_{C O}}{y_{H 2}+y_{C O}}+B\right)(1-0,0039(T-523))
$$

where $\mathrm{A}$ and $\mathrm{B}$ are coefficients with values of $0.2332 \pm 0.0740$ and $0.6330 \pm 0.0420$, respectively. Likewise, $y_{\mathrm{CO}}$ and $y_{\mathrm{H}_{2}}$ are the mole fractions of $\mathrm{CO}$ and $\mathrm{H}_{2}$ in the feed stream to the FT reactor, and $T(\mathrm{~K})$ is the operating temperature of the FT reactor. FT products 
were assumed to be composed only of paraffins and olefins, which are the main products of the LTFT synthesis [12]. Eq. (2) shows that the production of olefins $(O)$ with respect to paraffins $(P)$ varies exponentially with carbon number $(n)$ [21].

$$
O / P=\exp \left(-\frac{\Delta E}{R T} n\right)=e^{-c n}
$$

$O / P$ is the olefin-to-paraffin molar ratio, and $\Delta E$ is the change in the activation energy for the olefin desorption step per every $\mathrm{CH}_{2}$ group, caused by weak van der Waals forces. The value for $\Delta E$ is $1.1 \mathrm{~kJ} / \mathrm{mol} \mathrm{C}$ atom, which leads to a value of $c$ between 0.26 and 0.28 , for the temperature range of the FT reactor used in this research [21, 22]. On the other hand, product selectivity is usually described by a statistical distribution model known as the Anderson-Schulz-Flory (ASF) distribution law, which provides the molar fraction $\left(\alpha_{C n}\right)$ of hydrocarbons produced by FT synthesis (Eq. (3)) and depends on the number of carbon atoms of the produced hydrocarbons (n) [5]. Likewise, Eq. (4) gives the weight fraction $\left(w_{C n}\right)$ of formed hydrocarbons.

$$
\begin{aligned}
& \alpha_{C n}=\alpha^{n-1}(1-\alpha) \\
& w_{C n}=\alpha^{n-1}(1-\alpha)^{2} n
\end{aligned}
$$

An $\alpha$-value of 0.90 was obtained using the highest values for A and B in Eq. (1). This high value increases the product selectivity towards high molecular mass linear wax and diesel $[2,4]$. Figure 3 shows the evolution of weight distribution versus carbon number, matching typical values in LTFT process $[4,23]$. Larger quantities of liquid biofuels are achieved for higher $\alpha$-values. In this sense, cobalt-based catalysts allow a relatively high chain growth probability and a very low activity towards the undesired water-gas shift reaction [24]. 


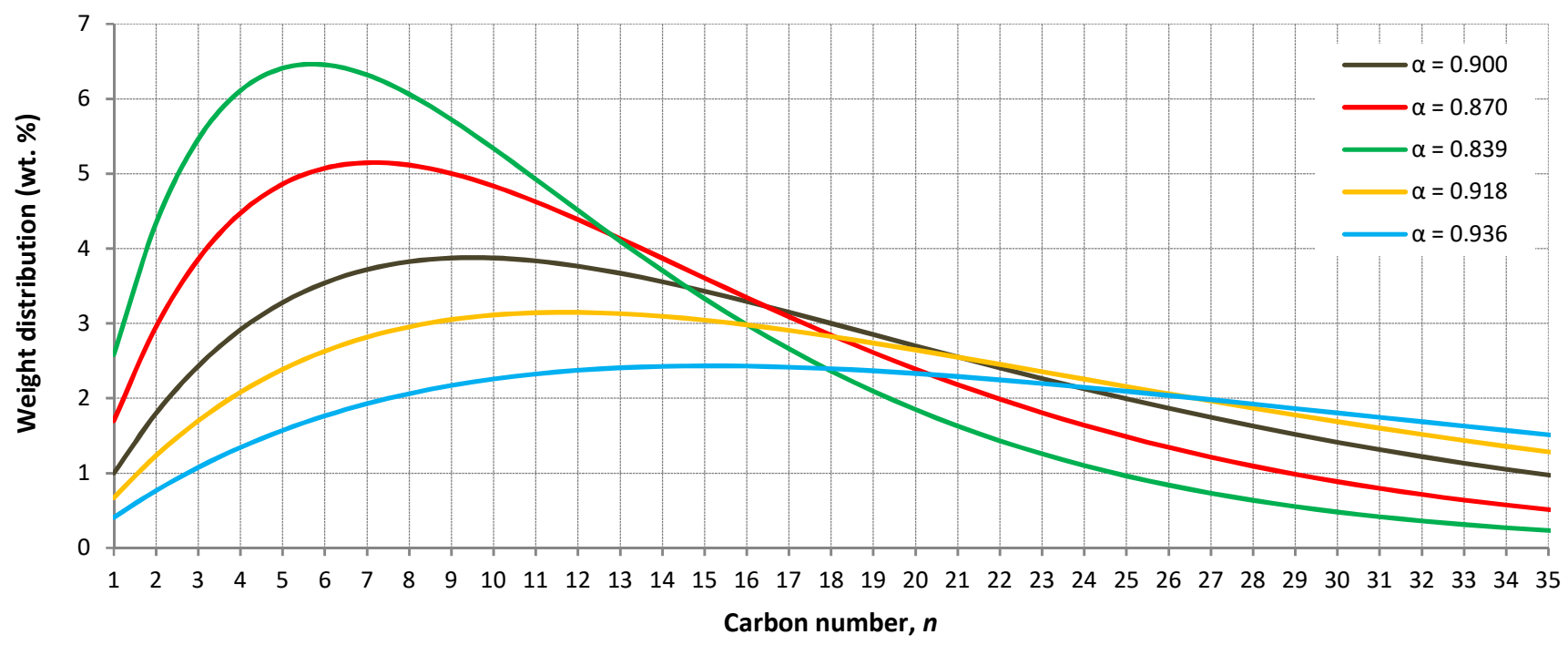

Figure 3. LTFT product weight distribution versus carbon number for different $\alpha$-values.

The FT product distribution is directly related to the $\mathrm{CO}$ fractional conversions relative to each hydrocarbon produced in the FT reactor, which depends on the $\alpha$-value and the paraffins-to-olefins ratio. Since $\alpha$-value depends on temperature and $\mathrm{H}_{2} / \mathrm{CO}$ molar ratio, these variables also influence on $\mathrm{CO}$ fractional conversions and the $\mathrm{CO}$ conversion per pass, but this latter does not affect the $\mathrm{CO}$ fractional conversions. Additionally, pressure must affect both $\alpha$-value and $\mathrm{CO}$ fractional conversions, but Eq. (1) does not consider the effect of pressure. Indeed, there is no an accepted equation that provides a relationship between pressure and $\alpha$-value. Thus, reported values for different pressures were used to inspect the effect of the pressure on the performance of the FT reactor [23].

In the base case, the LTFT reactor operates at 20 bar and $220{ }^{\circ} \mathrm{C}$, as well as with an inlet molar ratio $\mathrm{H}_{2} / \mathrm{CO}$ of 2.0, to promote FT reactions with Co-based catalysts that allow a long-chain hydrocarbon generation [4]. Under these conditions, $\mathrm{CO}$ conversion per pass was assumed to be $50 \%$, as previously reported [4, 25], and $\alpha$-value was 0.90 (computed by Eq. (1)). The stream leaving the FT reactor is cooled, so heavier hydrocarbons are condensed and separated from the gas, which is sent back to the FT reactor inlet through 
a recycle loop to maximize the overall CO conversion (about $87 \%$, as reported [26]) and to increase the specific production of liquid fuel. To avoid the build-up of inert gases, this configuration contains also a purge. On the other hand, the liquid phase leaving the loop is sent to a decanter for separating water from heavier hydrocarbons, which are expanded and sent to the distillation section.

\subsection{Refining and upgrading of Fischer-Tropsch products}

Purge from LTFT process and outlet stream from hydrocracking reactor are mixed and cooled to $35^{\circ} \mathrm{C}$, thus entering a flash separator to remove the gases (unconverted $\mathrm{CO}$ and $\mathrm{H}_{2}$, as well as $\mathrm{CO}_{2}, \mathrm{CH}_{4}$ and light hydrocarbons $\left.\left(\mathrm{C}_{2}-\mathrm{C}_{5}\right)\right)$ from the liquid, which contains traces of gaseous compounds. The liquid stream enters a distillation column (DEST1), so the light stream (at the top) is composed of jet fuel, gasoline, light hydrocarbons $\left(\mathrm{C}_{2}-\mathrm{C}_{4}\right.$ with somewhat of $\left.\mathrm{C}_{5}\right)$ and traces of water, $\mathrm{H}_{2}, \mathrm{CO}$ and $\mathrm{CO}_{2}$, and the heavy products (at the bottom) are composed of diesel and wax. These latter are separated in the second column (DEST2), where wax is sent to the hydrocracking reactor. Likewise, the stream leaving the top of DEST1 is fed into another column (DEST3) for separating jet fuel (at the bottom) and light gas and gasoline (at the top), which are further separated in a flash separator.

Hydrocracking process of long chain wax (heavier paraffins with a boiling point temperature higher than $370{ }^{\circ} \mathrm{C}$ [27]) is an effective route to maximize the production of high-quality middle distillates (diesel and jet fuel) in LTFT synthesis. The unconverted $\mathrm{H}_{2}$ from LTFT synthesis (and, if necessary, a fraction of the $\mathrm{H}_{2}$-rich stream leaving PSA1) is used as reactant for hydrogenation in the hydrocracking process. In this study, only alkanes with carbon number equal or higher than 20 are considered to react and hydrocracking products are alkanes with carbon number between 10 and 15 . Hydrocracking temperature must be higher than $280{ }^{\circ} \mathrm{C}[28]$ to maximize the selectivity 
of the $\mathrm{C}_{10}-\mathrm{C}_{20}$ fraction, for a bifunctional platinum-based catalyst [29]. The presence of $\mathrm{H}_{2} \mathrm{O}$ and $\mathrm{CO}$ might poison and deactivate the noble-metal hydrocracking catalyst [30]. Likewise, olefin production rate may increase with the $\mathrm{CO}$ concentration fed into the hydrocracking reactor, thus reducing the liquid fuel selectivity.

The carbon number distribution of cracked products is assumed as fully symmetrical and centered at around half of the original molecule, so equal molar amounts are formed [31]. This matches the result of that the most frequent product is shifted towards a number of carbon atoms that is slightly under the medium value [32]. Therefore, the reactions are:

$$
\begin{array}{ll}
\text { For even } \mathrm{n}: & \mathrm{C}_{\mathrm{n}} \mathrm{H}_{2 \mathrm{n}+2}+\mathrm{H}_{2} \rightarrow 2 \mathrm{C}_{\mathrm{n} / 2} \mathrm{H}_{2(\mathrm{n} / 2)+2} \\
\text { For odd } \mathrm{n}: & \mathrm{C}_{\mathrm{n}} \mathrm{H}_{2 \mathrm{n}+2}+\mathrm{H}_{2} \rightarrow \mathrm{C}_{(\mathrm{n}+1) / 2} \mathrm{H}_{2((\mathrm{n}+1) / 2)+2} \mathrm{C}_{(\mathrm{n}-1) / 2} \mathrm{H}_{2((\mathrm{n}-1) / 2)+2}
\end{array}
$$

A RStoic reactor is used to simulate the hydrocracker, where $\mathrm{CO}$ fractional conversions were specified according to results found in the literature [27], so the outlet stream has $32.90 \mathrm{wt} . \%$ of reactants (mass fraction of $\left.\mathrm{C}_{20+}\right)$ and $67.10 \mathrm{wt} \% \%(25.30 \%$ for jet fuel and $41.80 \%$ for diesel) of products (mass fraction of $\mathrm{C}_{10}-\mathrm{C}_{20}$ ). The hydrocracking operating conditions were $360{ }^{\circ} \mathrm{C}$ and 35 bar, and $0.06 \mathrm{~kg} \mathrm{H}_{2} / \mathrm{kg}$ wax, within the ranges previously reported $[12,27]$, to achieve a high extent of cracking reaction and to maximize the distillate fraction. Highly exothermic hydrogenation reaction and endothermic cracking reaction take place in the hydrocracking reactor, so the amount of heat released in the hydrogenation reactions might be higher or lower than the heat required for the endothermic cracking reactions. Although others have found an overall net heat slightly negative (exothermic) [33], all cases of this study presented a net heat slightly positive (endothermic), which increases as the amount of hydrogen fed into the reactor increases, because hydrogen absorbs a part of the released heat. Thus, this reactor is almost isothermal. Outlet stream from hydrocracking reactor is expanded to the pressure of purge of FT synthesis loop. 


\subsection{Composition and mass flow rate of the bio-oil aqueous phase}

Table 2 shows the feedstock composition of this process, representative of fast pyrolysis liquids from pine wood [34] for different total concentration (15-35 wt.\%). Besides, three values of inlet mass-flow $(20,60$ and $100 \mathrm{t} / \mathrm{h})$, within the range of industrial plants [35-37], and some changes in the concentrations of acetic acid, acetol and levoglucosan [38-40] were used in different simulations.

On the other hand, acetic acid, acetol and butanol are major constituents of the carboxylic acids, ketonic and alcohol fraction of bio-oil, and the supercritical water reforming of these model compounds, including glucose instead of levoglucosan [41], have been experimentally studied in our previous work [42]. Thus, Table 2 also includes the feedstock used in [42], which was simulated for a total concentration of $25 \mathrm{wt} . \%$ to compare with the results of the more complete composition.

Table 2. Case studies for different composition and total concentration of the bio-oil aqueous fractions

\begin{tabular}{|c|c|c|c|c|c|c|c|c|c|c|}
\hline Compound & Formula & $\begin{array}{l}\text { Case 1 } \\
\text { (wt.\%) }\end{array}$ & $\begin{array}{l}\text { Case 2 } \\
\text { (wt.\%) }\end{array}$ & $\begin{array}{l}\text { Case 3 } \\
\text { (wt.\%) }\end{array}$ & $\begin{array}{l}\text { Case } 4 \\
(\text { wt.\%) }\end{array}$ & $\begin{array}{l}\text { Case } 5 \\
\text { (wt.\%) }\end{array}$ & $\begin{array}{l}\text { Case 6 } \\
\text { (wt.\%) }\end{array}$ & $\begin{array}{l}\begin{array}{l}\text { Case } 7 \\
\text { (wt.\%) }\end{array} \\
\end{array}$ & $\begin{array}{l}\text { Case 8 } \\
\text { (wt.\%) }\end{array}$ & $\begin{array}{l}\text { Case } 9 \\
\text { (wt.\%) }\end{array}$ \\
\hline Acetic acid & $\mathrm{C}_{2} \mathrm{H}_{4} \mathrm{O}_{2}$ & 8.00 & 6.86 & 5.72 & 3.58 & 3.58 & 4.57 & 3.43 & 10.00 & 10.00 \\
\hline Hydroxyacetone & $\mathrm{C}_{3} \mathrm{H}_{6} \mathrm{O}_{2}$ & 5.00 & 4.29 & 3.58 & 5.72 & 3.58 & 2.86 & 2.14 & 5.00 & 5.00 \\
\hline 1-Butanol & $\mathrm{C}_{4} \mathrm{H}_{10} \mathrm{O}$ & 3.00 & 2.57 & 2.14 & 2.14 & 2.14 & 1.71 & 1.29 & 5.00 & 5.00 \\
\hline Acetaldehyde & $\mathrm{CH}_{3} \mathrm{CHO}$ & 1.00 & 0.86 & 0.71 & 0.71 & 0.71 & 0.57 & 0.43 & - & - \\
\hline Formic acid & $\mathrm{CH}_{2} \mathrm{O}_{2}$ & 3.00 & 2.57 & 2.14 & 2.14 & 2.14 & 1.71 & 1.29 & - & - \\
\hline Butyric acid & $\mathrm{C}_{4} \mathrm{H}_{8} \mathrm{O}_{2}$ & 2.00 & 1.71 & 1.44 & 1.44 & 1.44 & 1.14 & 0.86 & - & - \\
\hline Methanol & $\mathrm{CH}_{3} \mathrm{OH}$ & 1.50 & 1.28 & 1.07 & 1.07 & 1.07 & 0.86 & 0.64 & - & - \\
\hline Guaiacol & $\mathrm{C}_{7} \mathrm{H}_{8} \mathrm{O}_{2}$ & 1.00 & 0.86 & 0.71 & 0.71 & 0.71 & 0.57 & 0.43 & - & - \\
\hline Glyoxal & $\mathrm{C}_{2} \mathrm{H}_{2} \mathrm{O}_{2}$ & 1.00 & 0.86 & 0.71 & 0.71 & 0.71 & 0.57 & 0.43 & - & - \\
\hline Furfural & $\mathrm{C}_{5} \mathrm{H}_{4} \mathrm{O}_{2}$ & 1.00 & 0.86 & 0.71 & 0.71 & 0.71 & 0.57 & 0.43 & - & - \\
\hline 1,4-Hydroxybenzene & $\mathrm{C}_{6} \mathrm{H}_{6} \mathrm{O}_{2}$ & 1.00 & 0.86 & 0.71 & 0.71 & 0.71 & 0.57 & 0.43 & - & - \\
\hline Propionic acid & $\mathrm{C}_{3} \mathrm{H}_{6} \mathrm{O}_{2}$ & 1.00 & 0.86 & 0.71 & 0.71 & 0.71 & 0.57 & 0.43 & - & - \\
\hline Phenol & $\mathrm{C}_{6} \mathrm{H}_{6} \mathrm{O}$ & 1.50 & 1.28 & 1.07 & 1.07 & 1.07 & 0.86 & 0.64 & - & - \\
\hline Levoglucosan & $\mathrm{C}_{6} \mathrm{H}_{10} \mathrm{O}_{5}$ & 5.00 & 4.28 & 3.58 & 3.58 & 5.72 & 2.86 & 2.14 & 5.00 & - \\
\hline Glucose & $\mathrm{C}_{6} \mathrm{H}_{12} \mathrm{O}_{6}$ & - & - & - & - & - & - & - & - & 5.00 \\
\hline \multicolumn{2}{|l|}{ TOTAL } & 35.00 & $\mathbf{3 0 . 0 0}$ & 25.00 & 25.00 & 25.00 & 20.00 & 15.00 & 25.00 & 25.00 \\
\hline
\end{tabular}




\subsection{Simulation remarks and components from databank}

Simulation was carried out using Aspen Plus version 8.0 (Aspen Technology, Inc., USA) to compute the mass and energy balances under different operating conditions. The thermodynamic methods were the predictive Soave-Redlich-Kwong (PSRK) Equation of state (EoS) for SCWR section [7], UNIQUAC for distillation train, STEAM-NBS for steam turbine (TURB2), and Peng-Robinson EoS, which is recommended when dealing with hydrocarbons, for the rest of the plant (PSA systems, as well as DR, FT and hydrocracking reactors).

The organic compounds conversions were always $100 \%$ (equilibrium conditions) in SCWR reactor (RGibbs) and HWGS reactor (REquil), but not in DR reactor that also operates at equilibrium conditions (REquil). The process simulation includes 66 chemical compounds, like $\mathrm{O}_{2}, \mathrm{~N}_{2}, \mathrm{H}_{2}, \mathrm{CO}_{2}, \mathrm{CH}_{4}, \mathrm{CO}$, glucose, water and all organic compounds shown in Table 2, apart from all the linear hydrocarbons from $\mathrm{C}_{2}$ to $\mathrm{C}_{30}$ for paraffins and $\mathrm{C}_{2}$ to $\mathrm{C}_{16}$ for olefins that represent the products of FT synthesis. As FT synthesis produces mainly linear hydrocarbons, and saturated hydrocarbons are barely representative, only linear hydrocarbons were selected to describe light (fuel) gas, gasoline, jet fuel, diesel and wax $[4,12]$, defined as those biofuel cuts including hydrocarbons $\mathrm{C}_{2}-\mathrm{C}_{4}, \mathrm{C}_{5}-\mathrm{C}_{9}$, $\mathrm{C}_{10}-\mathrm{C}_{13}, \mathrm{C}_{14}-\mathrm{C}_{20}$, and $\mathrm{C}_{20+}$, respectively, similar to those previously reported $[43,44]$. Recovery fractions of hydrocarbons for each distillation column are presented in Table 1, and they were chosen to achieve technical specifications, such as density, viscosity or cetane number, in liquid biofuels, thus minimizing the number of stages in each distillation column.

\section{On the process optimization}

The aim was to maximize the process performance in terms of carbon efficiency with or without refining (i.e., at the outlet of the FT synthesis loop or at the outlet of the 
process, just leaving the distillation section), as well as biofuel and electricity production, for a given mass flow-rate and total organic concentration of the bio-oil aqueous phase fed into the process. As a constraint, the process must be energy self-sufficient, so offgases with chemical energy must be sent to the furnace. The total net power is the power of the two turbines minus the consumed power in all the pumps, fans and compressors.

Some potential optimization variables were fixed, such as the reforming pressure at 240 bar since it barely affects the process in the range from 200 to 300 bar [7]. The outlet pressure of the expander downstream from the SCWR reactor was 40 bar, as it is the minimum required to optimize the subsequent heat exchange that allows the maximization of biofuel and electricity production, as well as the separation to be performed in the PSA system. The optimal reforming temperature is between 750 and $800{ }^{\circ} \mathrm{C}$ to increase the $\mathrm{CO}$ and $\mathrm{H}_{2}$ yields, and since higher temperatures involve slight gains of those yields but much more energy requirement, $800{ }^{\circ} \mathrm{C}$ was chosen. Similarly, the pressure and temperature of the HWGS (operating at the outlet pressure of the first expander), DR and hydrocracking reactors were the usual in these reactors for a good performance.

The purge (or recirculation) of the FT synthesis loop may be also optimized, and a minimum purge is necessary to avoid accumulation of inert gases in the FT synthesis loop. However, if the purge ratio increases, the overall $\mathrm{CO}$ conversion and biofuels production will decrease although, at the same time, a higher flow-rate of residual gases may be sent to furnace. Nevertheless, instead of burning a processed product (leaving the FT synthesis loop), a better option consists of burning a less processed product gas obtained upstream. In this way, a variable fraction of product gas is sent to furnace, and the recirculation-to-purge ratio is maximized. Simulations of both options (combustion of a fraction of product gas or a higher purge of FT synthesis loop) resulted in similar 
performance parameters. Therefore, an overall $\mathrm{CO}$ conversion regarding maximum recycle-to-purge ratio was $87 \%$, which also maximizes the biofuel production in the FT synthesis loop. In this sense and to clarify, in this study, no reactor and separation systems is sized, so the effects of different operating variables must be understood without the constraint relative to the real unit size. Thus, e.g., although molar-flows of gases at inlet LTFT stream vary in the case-studies performed in the sensitivity analysis, CO conversion per pass is assumed to be constant if the $\mathrm{H}_{2} / \mathrm{CO}$ molar ratio, pressure and temperature are kept constant. However, if FT reactor was sized, the CO conversion per pass would be influenced by molar flow-rates of gases entering the reactor that would affect the unit performance. This will be considered in a future techno-economic assessment.

Thus, in summary, there are still some independent variables for optimization: the total organic concentration in the aqueous phase of bio-oil in the feed, and the operating conditions of the FT reactor. SCW reforming is clearly interesting when the feed has much water, so 15 to $35 \mathrm{wt} . \%$ are realistic feed concentration values for the aqueous phase of the bio-oil. More diluted concentrations imply higher energy demand, so energy selfsufficiency constraint may be violated. Likewise, high feed concentrations lead to a heat surplus in the overall process, and other reforming processes may be more suitable. Finally, the operating conditions of the FT reactor are referred to pressure, temperature and $\mathrm{H}_{2} / \mathrm{CO}$ molar ratio, and the normal ranges for Co-based LTFT reactors (20-40 bar, $220-240{ }^{\circ} \mathrm{C}$ and $1.7-2.3$ for $\mathrm{H}_{2} / \mathrm{CO}$ molar ratio) are inspected.

\section{Results and discussion}

The base-case corresponds to an aqueous fraction of bio-oil with mass flow of $60 \mathrm{t} / \mathrm{h}$ and 25 wt. $\%$, where the FT reactor operates at $220^{\circ} \mathrm{C}, 20$ bar, and $\mathrm{H}_{2} / \mathrm{CO}$ molar ratio of 2.0. CO conversion per pass and $\alpha$-value were $50 \%$ and 0.90 , respectively. Table 3 shows 
the overall energy balance and the heat flows for all the heat exchangers. Table 4 provides the comparison of biofuels properties with those obtained in literature and standards, so a good match is achieved. Table 5 presents summarized simulation results for the main process streams, such as components and overall mass flow-rates, temperatures and pressures, which allows a comprehensive analysis of the process.

Table 6 illustrates the results of varying different operating parameters regarding the bio-oil aqueous phase (sensitivity analysis) and how they affect the production of LTFT products, electricity, as well as cogeneration water, which is discussed below. The main loss of carbon fed into the process is through the produced $\mathrm{CO}_{2}$, which is efficiently separated with high purity for sequestration, and light hydrocarbons $\left(\mathrm{CH}_{4}\right.$ and $\left.\mathrm{C}_{2}-\mathrm{C}_{4}\right)$, which are burnt for achieving the overall energy self-sufficiency of the process.

Table 3. Overall energy balance for reforming of bio-oil aqueous phase using SCW and LTFT synthesis, and heat flows for all the heat exchangers (base case/case 3).

\begin{tabular}{|c|c|c|c|c|c|c|c|}
\hline \multicolumn{2}{|c|}{ Work entering the system $(\mathrm{kW})$} & \multicolumn{2}{|c|}{ Enthalpy of the inlet streams $(\mathrm{kW})$} & \multirow{2}{*}{$\begin{array}{c}\text { Unit } \\
\text { HE01 }\end{array}$} & \multirow{2}{*}{$\begin{array}{c}\mathbf{Q}(\mathbf{k W}) \\
18058.2\end{array}$} & \multirow{2}{*}{$\begin{array}{c}\text { Unit } \\
\mathrm{C} 1\end{array}$} & \multirow{2}{*}{$\begin{array}{r}\mathbf{Q}(\mathbf{k W}) \\
5178.3\end{array}$} \\
\hline $\mathrm{P} 1$ & 687.52 & Aqueous phase of bio-oil & -223497.54 & & & & \\
\hline $\mathrm{P} 2$ & 5.56 & Air & -3.60 & HE02 & 4640.4 & $\mathrm{C} 2$ & 112.3 \\
\hline P3-P4 & 22.91 & W1 & -859707.45 & HE03 & 5598.8 & $\mathrm{C} 3$ & 322.1 \\
\hline P5-P7 & 1.49 & W2 & -17635.02 & HE04 & 1317.0 & $\mathrm{C} 4$ & 138.2 \\
\hline FAN1 & 185.70 & W3 & -397229.11 & HE05 & 19163.4 & $\mathrm{C} 5$ & 9804.3 \\
\hline COMP1-COMP4 with inter. cool. & 5010.27 & W4 & -11991.79 & HE06 & 762.7 & H1 & 1013.7 \\
\hline \multirow[t]{3}{*}{ COMP5-COMP7 } & 29.40 & W5 & -95229.16 & HE07 & 2093.1 & $\mathrm{H} 2$ & 223.9 \\
\hline & & & & HE08 & 100.1 & H3 & 253.0 \\
\hline & & & & HE09 & 552.9 & & \\
\hline TOTAL & 5942.85 & & & HE10 & 109.3 & & \\
\hline \multicolumn{2}{|c|}{ Work leaving the system $(\mathrm{kW})$} & \multicolumn{2}{|c|}{ Enthalpy of the outlet streams $(\mathrm{kW})$} & HE11 & 2435.9 & & \\
\hline Turbine TURBINE & -9995.65 & Separated water (14-O) & -176284.47 & HE12 & 111.8 & & \\
\hline \multirow[t]{5}{*}{ Turbine TURB2 } & -1674.77 & Separated water (29-O) & -112.40 & HE13 & 4731.7 & & \\
\hline & & Separated water (45-O) & -17344.22 & HE14 & 626.0 & & \\
\hline & & Cogeneration water (WC) & -1353956.55 & HE15 & 103.0 & & \\
\hline & & $\mathrm{CO}_{2}$ sequestered $\left(\mathrm{CO}_{2}-\mathrm{O}\right)$ & -14331.79 & HE16 & 1061.8 & & \\
\hline & & Tail gas & -54514.52 & HE17 & 8396.7 & & \\
\hline TOTAL & -11670.42 & & & HE18 & 7642.4 & & \\
\hline
\end{tabular}


Table 4. Comparison of biofuels properties with standards and other sources

\begin{tabular}{|c|c|c|c|c|c|c|c|c|c|c|c|c|}
\hline \multirow{2}{*}{$\begin{array}{c}\text { Elemental } \\
\text { analysis and } \\
\text { properties }\end{array}$} & \multicolumn{3}{|c|}{ In this study } & \multicolumn{3}{|c|}{ Typical US Refiners [51] } & \multicolumn{2}{|c|}{$\begin{array}{l}\text { UNE-EN-ISO } 3675, \\
\text { UNE-EN-ISO 12185, } \\
\text { ASTM D 4052, } \\
\text { ASTM D } 1298\end{array}$} & \multirow{2}{*}{$\begin{array}{c}\text { ASTM } \\
\text { D } 1655 \\
\text { Jet } \\
\text { Fuel }\end{array}$} & \multicolumn{3}{|c|}{$\begin{array}{c}\text { Shell Bintulu LTFT } \\
\text { refinery [43] }\end{array}$} \\
\hline & Gasoline & Diesel & $\begin{array}{c}\text { Jet } \\
\text { Fuel }\end{array}$ & Gasoline & Diesel & $\begin{array}{c}\text { Jet } \\
\text { Fuel }\end{array}$ & Gasoline & Diesel & & Gasoline & Diesel & $\begin{array}{c}\text { Jet } \\
\text { Fuel }\end{array}$ \\
\hline C (wt.\%) & 85.20 & 85.93 & 86.65 & $85-88$ & $84-87$ & 87.0 & - & - & - & - & - & - \\
\hline H (wt.\%) & 14.80 & 14.07 & 13.35 & $15-17$ & $16-33$ & 12.3 & - & - & - & - & - & - \\
\hline O (wt.\%) & 0.00 & 0.00 & 0.00 & 0.00 & 0.00 & 0.5 & - & - & - & - & - & - \\
\hline $\mathrm{H} / \mathrm{C}$ molar & 2.25 & 2.13 & 2.18 & - & - & 1.70 & - & - & - & - & - & - \\
\hline $\mathrm{MW}(\mathrm{g} / \mathrm{mol})$ & 99.84 & 211.74 & 153.77 & 100 & 200 & - & - & - & - & - & - & - \\
\hline $\begin{array}{c}\text { Density }\left(\mathrm{g} / \mathrm{cm}^{3}\right) \\
\text { at } 15^{\circ} \mathrm{C}\end{array}$ & 0.70 & 0.81 & 0.76 & 0.75 & 0.85 & - & $0.72-0.78$ & $0.82-0.89$ & $\begin{array}{l}0.78- \\
0.84\end{array}$ & 0.69 & 0.78 & 0.74 \\
\hline $\begin{array}{c}\text { Viscosity }(\mathrm{cP}) \\
\text { at } 15^{\circ} \mathrm{C} \\
\end{array}$ & 0.42 & 3.46 & 1.24 & $0.37-0.44$ & $2.6-4.1$ & - & - & - & - & - & - & - \\
\hline $\begin{array}{c}\text { Aromatics (wt. } \\
\% \text { ) }\end{array}$ & 0 & 0 & 0 & 31 & - & $<22$ & $\begin{array}{l}35 \% \\
(\operatorname{Max}) \\
\end{array}$ & - & $\begin{array}{l}25 \% \\
(\mathrm{Max})\end{array}$ & 0 & $<0.05$ & $<0.1$ \\
\hline Cetane index & - & 97 & 80 & - & $40-55$ & - & - & 51 (Min) & - & - & 76 & 58 \\
\hline
\end{tabular}


Table 5. Simulations results for the main process streams (base-case/case 3 : feed of $60 \mathrm{t} / \mathrm{h}$; SCW reforming at $800{ }^{\circ} \mathrm{C}$ and 240 bar; dry reforming at $600{ }^{\circ} \mathrm{C}$ and 1 bar; LTFT conditions: $220^{\circ} \mathrm{C}, 20$ bar and $\mathrm{H}_{2} / \mathrm{CO}$ ratio of 2.0 ).

\begin{tabular}{|c|c|c|c|c|c|c|c|c|c|c|c|c|c|c|c|}
\hline \multicolumn{2}{|l|}{ Stream } & 06 & 07 & 10 & 14 & 15 & 16-H & 17-H-C & $20-\mathrm{CO}$ & 22 & 23 & 30 & 31-H & 35-CO & T-MIX9 \\
\hline \multicolumn{2}{|l|}{ From } & HE04 & SCWR & SP1 & SEP & SP2 & PSA1 & SP3 & V4 & HE07 & DRYREF & COMP2 & PSA1A & V6 & SP6 \\
\hline \multicolumn{2}{|l|}{ To } & SCWR & TURB & MIX1 & SP2 & PSA1 & SP3 & MIX6 & MIX2 & DRYREF & HE04 & PSA1A & MIX3 & MIX2 & MIX9 \\
\hline $\mathrm{H}_{2} \mathrm{O}$ & $\mathrm{kg} / \mathrm{h}$ & 45000 & 39926.9 & 39926.9 & 41.7 & 33.5 & 0 & 0 & 0 & 33.5 & 33.5 & 7.8 & 0 & 0 & 0 \\
\hline $\begin{array}{l}\text { Total organic } \\
\text { compounds }\end{array}$ & $\mathrm{kg} / \mathrm{h}$ & 15000 & 0 & 0 & 0 & 0 & 0 & 0 & 0 & 0 & 0 & 0 & 0 & 0 & 0 \\
\hline $\mathrm{H}_{2}$ & $\mathrm{~kg} / \mathrm{h}$ & 0 & 968.6 & 968.6 & 967.5 & 776.9 & 738.1 & 8.1 & 0 & 38.8 & 328.4 & 328.4 & 312.0 & 0 & 16.3 \\
\hline $\mathrm{CO}_{2}$ & $\mathrm{~kg} / \mathrm{h}$ & 0 & 12344.6 & 12344.6 & 11980.9 & 9620.7 & 0 & 0 & 96.8 & 9524.5 & 6364.1 & 6364.1 & 0 & 63.8 & 567.0 \\
\hline $\mathrm{CH}_{4}$ & $\mathrm{~kg} / \mathrm{h}$ & 0 & 2895.0 & 2895.0 & 2890.3 & 2320.9 & 0 & 0 & 23.2 & 2297.7 & 1145.6 & 1145.6 & 0 & 11.5 & 1089.9 \\
\hline $\mathrm{CO}$ & $\mathrm{kg} / \mathrm{h}$ & 0 & 3864.1 & 3864.1 & 3859.7 & 3099.3 & 0 & 0 & 3037.3 & 62.0 & 4084.9 & 4084.9 & 0 & 4003.2 & 81.3 \\
\hline Mass Flow & $\mathrm{kg} / \mathrm{h}$ & 60000 & 60000 & 60000 & 19740.5 & 15851.3 & 738.1 & 8.1 & 3157.3 & 11956.5 & 11956.5 & 11930.8 & 312.0 & 4078.5 & 1754.5 \\
\hline Temperature & ${ }^{\circ} \mathrm{C}$ & 374 & 800 & 350 & 35.0 & 35.0 & 35.0 & 35.0 & 32.0 & 600 & 600 & 35.0 & 35.0 & 32.0 & 32.0 \\
\hline Pressure & bar & 240 & 240 & 40.0 & 39.9 & 39.9 & 39.9 & 39.9 & 1.0 & 1.0 & 1.0 & 20.1 & 20.1 & 1.0 & 1.0 \\
\hline \multicolumn{2}{|l|}{ Stream } & 40 & 41 & 44 & 45 & 47-R & WAX & 46-HYD & 50-L & 51-G & 52-G & $56-G$ & T-HE02 & 52 & 54 \\
\hline \multicolumn{2}{|l|}{ From } & HE12 & RFT & SEP3 & DECANT & COMP5 & P2 & V8 & SEP4 & SP5 & PSA4 & MIX10 & C1 & V7 & DEST1 \\
\hline \multicolumn{2}{|l|}{ To } & RFT & HE13 & DECANT & MIX7 & MIX4 & HE15 & MIX5 & MIX7 & MIX8 & MIX8 & HE17 & HE02 & DEST1 & DEST3 \\
\hline $\mathrm{H}_{2} \mathrm{O}$ & $\mathrm{kg} / \mathrm{h}$ & 11.1 & 3925.4 & 3912.7 & 4.1 & 11.1 & 0 & 0 & 1.9 & 0.1 & 0 & 8.8 & 7376.9 & 6.0 & 6.0 \\
\hline $\mathrm{H}_{2}$ & $\mathrm{~kg} / \mathrm{h}$ & 1758.3 & 843.1 & 0.4 & 0.4 & 716.3 & 0 & 92.1 & 0 & 123.8 & 4.7 & 335.8 & 0 & 0.4 & 0.4 \\
\hline $\mathrm{CO}_{2}$ & $\mathrm{~kg} / \mathrm{h}$ & 660.6 & 660.6 & 71.6 & 71.3 & 500.0 & 0 & 0 & 1.1 & 49.3 & 37.8 & 3086.7 & 11633.4 & 72.4 & 72.4 \\
\hline $\mathrm{CH}_{4}$ & $\mathrm{~kg} / \mathrm{h}$ & 381.8 & 416.7 & 8.3 & 8.3 & 347.1 & 0 & 0 & 0.2 & 34.6 & 26.5 & 1728.9 & 0 & 8.5 & 8.5 \\
\hline $\mathrm{CO}$ & $\mathrm{kg} / \mathrm{h}$ & 12173.8 & 6087.3 & 48.1 & 48.1 & 5133.3 & 0 & 0 & 0.9 & 512.6 & 392.4 & 1795.9 & 0 & 49.2 & 49.2 \\
\hline $\mathrm{C}_{2}-\mathrm{C}_{4}{ }^{(1)}$ & $\mathrm{kg} / \mathrm{h}$ & 254.2 & 479.7 & 180.8 & 180.8 & 254.2 & 0 & 0 & 2.3 & 24.0 & 18.4 & 207.2 & 0 & 183.2 & 183.2 \\
\hline $\mathrm{C}_{5}-\mathrm{C}_{9}{ }^{(2)}$ & $\mathrm{kg} / \mathrm{h}$ & 10.4 & 571.8 & 559.6 & 559.6 & 10.4 & 0 & 0 & 1.1 & 0.4 & 0.3 & 114.5 & 0 & 560.7 & 560.7 \\
\hline $\mathrm{C}_{10}-\mathrm{C}_{13}{ }^{(3)}$ & $\mathrm{kg} / \mathrm{h}$ & 0 & 461.8 & 461.8 & 461.8 & 0 & 0 & 436.2 & 435.8 & 0.2 & 0.2 & 0.4 & 0 & 897.6 & 875.4 \\
\hline $\mathrm{C}_{14}-\mathrm{C}_{20}{ }^{(4)}$ & $\mathrm{kg} / \mathrm{h}$ & 0 & 687.1 & 687.1 & 687.1 & 0 & 15.8 & 685.8 & 685.8 & 0 & 0 & 0 & 0 & 1372.9 & 21.9 \\
\hline $\mathrm{C}_{20+}{ }^{(5)}$ & $\mathrm{kg} / \mathrm{h}$ & 0 & 1116.7 & 1116.7 & 1116.7 & 0 & 1619.7 & 519.2 & 519.2 & 0 & 0 & 0 & 0 & 1635.9 & 0 \\
\hline $\mathrm{O}_{2}$ & $\mathrm{~kg} / \mathrm{h}$ & 0 & 0 & 0 & 0 & 0 & 0 & 0 & 0 & 0 & 0 & 13987.2 & 2255.1 & 0 & 0 \\
\hline $\mathrm{N}_{2}$ & $\mathrm{~kg} / \mathrm{h}$ & 0 & 0 & 0 & 0 & 0 & 0 & 0 & 0 & 0 & 0 & 45975.0 & 45975.0 & 0 & 0 \\
\hline Mass Flow & $\mathrm{kg} / \mathrm{h}$ & 15250.2 & 15250.2 & 7047.1 & 3138.2 & 6972.4 & 1635.5 & 1733.3 & 1648.3 & 745.0 & 480.3 & 67240.4 & 67240.4 & 4786.8 & 1777.7 \\
\hline Temperature & ${ }^{\circ} \mathrm{C}$ & 220 & 220 & 35.0 & 35.0 & 37.1 & 427.4 & 353.5 & 35.0 & 35.0 & 35.0 & 112.1 & 791.3 & 35.7 & 99.1 \\
\hline Pressure & bar & 20.0 & 20.0 & 19.9 & 19.7 & 20.0 & 35.0 & 20.0 & 20.0 & 20.0 & 20.0 & 1.0 & 1.0 & 1.5 & 1.3 \\
\hline
\end{tabular}

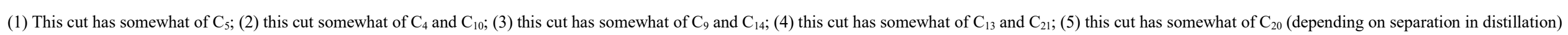


Table 6. Sensitivity analysis results (biofuels and net electrical power production, carbon efficiencies, $\mathrm{CO}_{2}$ mass flow and cogeneration water) varying aqueous phase of biooil in: (1) total concentration, (2) total mass flow rate, (3) composition.

\begin{tabular}{|c|c|c|c|c|c|c|c|c|c|c|c|c|c|}
\hline \multicolumn{14}{|c|}{ Sensitivity analysis varying aqueous fraction of bio-oil } \\
\hline \multicolumn{14}{|c|}{$60 \mathrm{t} / \mathrm{h}$; LTFT conditions: $220^{\circ} \mathrm{C} ; 20 \mathrm{bar} ; \mathrm{H}_{2} / \mathrm{CO}=2.00$ and $\mathrm{CO}$ conversion per pass: $50 \%$} \\
\hline $\begin{array}{l}\text { Aqueous fraction } \\
\text { (wt. \%) }\end{array}$ & $\begin{array}{c}\text { Pressure } \\
\text { turbine (bar) }\end{array}$ & $\begin{array}{c}\text { FT-diesel } \\
(\mathrm{kg} / \mathrm{h})\end{array}$ & $\begin{array}{c}\text { FT-jet fuel } \\
(\mathrm{kg} / \mathrm{h})\end{array}$ & $\begin{array}{c}\text { FT-gasoline } \\
(\mathrm{kg} / \mathrm{h})\end{array}$ & $\begin{array}{c}\text { Biomethane } \\
(\mathrm{kg} / \mathrm{h})\end{array}$ & \multicolumn{2}{|c|}{$\begin{array}{c}\text { Carbon efficiency } \\
\text { without refining }\end{array}$} & $\begin{array}{c}\text { Carbon efficiency } \\
\text { with refining }\end{array}$ & \multicolumn{2}{|c|}{$\begin{array}{c}\text { Electricity } \\
(\mathrm{kW})\end{array}$} & \multicolumn{2}{|c|}{$\begin{array}{c}\mathrm{CO}_{2} \text { sequestered } \\
(\mathrm{kg} / \mathrm{h})\end{array}$} & $\begin{array}{l}\text { Cogeneration } \\
\text { water }(\mathrm{t} / \mathrm{h})\end{array}$ \\
\hline 35 (Case1) & 18.5 & 2174 & 1420 & 737 & 91 & \multicolumn{2}{|c|}{40.99} & 36.84 & \multicolumn{2}{|l|}{5441} & \multicolumn{2}{|l|}{10720} & 366.8 \\
\hline 35 (Case1) & 17.0 & 2174 & 1420 & 737 & - & \multicolumn{2}{|c|}{40.99} & 36.31 & \multicolumn{2}{|l|}{5656} & \multicolumn{2}{|l|}{10720} & 366.8 \\
\hline 30 (Case2) & 40.0 & 1818 & 1188 & 593 & - & \multicolumn{2}{|c|}{40.01} & 35.26 & \multicolumn{2}{|l|}{4030} & \multicolumn{2}{|l|}{8265} & 355.7 \\
\hline 25 (Case 3) & 40.0 & 1374 & 898 & 467 & - & \multicolumn{2}{|c|}{36.26} & 32.18 & \multicolumn{2}{|l|}{5728} & \multicolumn{2}{|l|}{5786} & 314.1 \\
\hline 20 (Case 6) & 40.0 & 824 & 538 & 268 & - & \multicolumn{2}{|c|}{27.19} & \multirow{2}{*}{23.95} & \multicolumn{2}{|l|}{7253} & \multicolumn{2}{|l|}{4009} & 301.2 \\
\hline 15 (Case 7) & 40.0 & 255 & 167 & 81 & - & \multicolumn{2}{|c|}{11.22} & & \multicolumn{2}{|l|}{8682} & \multicolumn{2}{|l|}{1540} & 273.3 \\
\hline & & & & Sensitivi & ty analysis $v$ & rying to & tal mass & flow & & & & & \\
\hline & & 25 wt. $\%$ & LTFT con & litions: 220 & C; 20 bar; $H$ & $2 / \mathrm{CO}=2$ & .0 and $C$ & CO conversion & er pass: 50 & & & & \\
\hline $\begin{array}{c}\text { Total mass flow } \\
(\mathrm{t} / \mathrm{h})\end{array}$ & $\begin{array}{c}\text { Pressure } \\
\text { turbine (bar) }\end{array}$ & $\begin{array}{c}\text { FT-diesel } \\
(\mathrm{kg} / \mathrm{h})\end{array}$ & $\begin{array}{c}\text { FT-jet fuel } \\
(\mathrm{kg} / \mathrm{h})\end{array}$ & $\begin{array}{c}\text { FT-gasoline } \\
(\mathrm{kg} / \mathrm{h})\end{array}$ & $\begin{array}{c}\text { Biomethane } \\
(\mathrm{kg} / \mathrm{h})\end{array}$ & $\begin{array}{l}\text { Carbon e } \\
\text { without }\end{array}$ & $\begin{array}{l}\text { fficiency } \\
\text { refining }\end{array}$ & $\begin{array}{c}\text { Carbon efficienc } \\
\text { with refining }\end{array}$ & $\begin{array}{r}\text { Electrici } \\
(\mathrm{kW})\end{array}$ & & $\begin{array}{c}\mathrm{CO}_{2} \text { sequeste } \\
(\mathrm{kg} / \mathrm{h})\end{array}$ & red & $\begin{array}{l}\text { Cogeneration } \\
\text { water }(\mathrm{t} / \mathrm{h})\end{array}$ \\
\hline 60.0 & 40.0 & 1374 & 898 & 467 & - & 36 & & 32.18 & 5728 & & 5786 & & 314.1 \\
\hline 100.0 & 40.0 & 2289 & 1496 & 779 & - & 36 & & 32.18 & 9566 & & 9643 & & 502.2 \\
\hline 20.0 & 40.0 & 458 & 299 & 156 & - & 36 & & 32.18 & 1908 & & 1911 & & 108.0 \\
\hline & & & sitivity ana & lysis varying & individual c & mpoun & Is of aqu & ueous fraction & bio-oil & & & & \\
\hline & & $60 \mathrm{t} / \mathrm{h} ; 25 \mathrm{wt}$ & $\%$; LTFT & conditions: & $20^{\circ} \mathrm{C} ; 20 \mathrm{~b}$ & $\mathrm{H}_{2} / \mathrm{CO}$ & $=2.0 \mathrm{an}$ & nd $\mathrm{CO}$ conversi & on per pass: & 50 & & & \\
\hline $5.71 \%(\max )$ & $3.57 \%(\mathrm{~min})$ & $\begin{array}{c}\text { Pressure } \\
\text { turbine (bar) }\end{array}$ & $\begin{array}{c}\text { FT-diesel } \\
(\mathrm{kg} / \mathrm{h})\end{array}$ & $\begin{array}{c}\begin{array}{c}\text { FT-jet fuel } \\
(\mathrm{kg} / \mathrm{h})\end{array} \\
\end{array}$ & $\begin{array}{c}\text { FT-gasoline } \\
(\mathrm{kg} / \mathrm{h})\end{array}$ & $\begin{array}{r}\text { Carbon e } \\
\text { without }\end{array}$ & $\begin{array}{l}\text { fficiency } \\
\text { refining }\end{array}$ & $\begin{array}{c}\text { Carbon efficienc } \\
\text { with refining }\end{array}$ & $\begin{array}{r}\text { Electrici } \\
(\mathrm{kW})\end{array}$ & & $\begin{array}{c}\mathrm{CO}_{2} \text { sequeste } \\
(\mathrm{kg} / \mathrm{h})\end{array}$ & red & $\begin{array}{c}\text { Cogeneration } \\
\text { water }(\mathrm{t} / \mathrm{h})\end{array}$ \\
\hline $\mathrm{AC}$ & LV-HY & 40.0 & 1374 & 898 & 467 & 36 & & 32.18 & 5728 & & 5786 & & 314.1 \\
\hline LV & AC-HY & 40.0 & 1397 & 913 & 470 & 36 & & 32.41 & 5680 & & 5863 & & 320.7 \\
\hline $\mathrm{HY}$ & AC-LV & 40.0 & 1435 & 938 & 483 & 37 & & 33.06 & 5618 & & 5893 & & 325.0 \\
\hline & Sensitivi & y analysis va & ing indivi & dual compou & ids of aque & s fract & on of bio & 0 -oil (10-5-5-5 v & t. \% AC-BL & $T$ & LV (GL)) & & \\
\hline & & $0 \mathrm{t} / \mathrm{h} ; 25 \mathrm{v}$ & $\%$; LTFT & conditions: 2 & $0^{\circ} \mathrm{C} ; 20 \mathrm{bc}$ & $; \mathrm{H}_{2} / \mathrm{CO}$ & $=2.0 \mathrm{an}$ & nd $\mathrm{CO}$ convers & on per pass: & 50 & & & \\
\hline Case-study & $\begin{array}{c}\text { Pressure } \\
\text { turbine (bar) }\end{array}$ & $\begin{array}{c}\text { FT-diesel } \\
(\mathrm{kg} / \mathrm{h})\end{array}$ & $\begin{array}{c}\text { FT-jet fuel } \\
(\mathrm{kg} / \mathrm{h})\end{array}$ & $\begin{array}{c}\text { FT-gasoline } \\
(\mathrm{kg} / \mathrm{h})\end{array}$ & $\begin{array}{l}\text { Carbon ef } \\
\text { without } \mathrm{r}\end{array}$ & $\begin{array}{l}\text { iciency } \\
\text { fining }\end{array}$ & $\begin{array}{r}\text { Carbon } \mathrm{e} \\
\mathrm{re}\end{array}$ & $\begin{array}{l}\text { efficiency with } \\
\text { refining }\end{array}$ & $\begin{array}{l}\text { Electricity } \\
(\mathrm{kW})\end{array}$ & & $\begin{array}{l}\text { sequestered } \\
(\mathrm{kg} / \mathrm{h})\end{array}$ & $\operatorname{Cog}$ & $\begin{array}{l}\text { eneration water } \\
(\mathrm{kg} / \mathrm{h})\end{array}$ \\
\hline Base-case & 40.0 & 1374 & 898 & 467 & 36.2 & & & 32.18 & 5728 & & 5786 & & 314.1 \\
\hline AC-BU-HY-LV & 40.0 & 1429 & 933 & 470 & 38.0 & & & 33.57 & 5724 & & 5657 & & 321.2 \\
\hline AC-BU-HY-GL & 40.0 & 1378 & 901 & 451 & 37.3 & & & 32.96 & 5873 & & 5500 & & 320.1 \\
\hline
\end{tabular}




\subsection{Effect of the concentration of bio-oil aqueous phase}

The overall energy demand in the process increases significantly as the organic feed concentration decreases, so the flow rate of product gas derived to furnace must increase for achieving energy self-sufficiency. Thus, for $15 \mathrm{wt} . \%, 73.5 \%$ of product gas must be burnt; for $25 \mathrm{wt} . \%$ that fraction decreases to $18.9 \%$, and for $35 \mathrm{wt} . \%$ there is no need of burning product gas. Consequently, at low concentrations, the specific biofuels production (in relation to feed) is clearly reduced, and carbon efficiencies after refining are low, in special for $15 \mathrm{wt} . \%$ where only $9.85 \%$ of total carbon fed into plant is present in biofuels leaving the process. For the base-case, carbon efficiency after refining is 32.18 $\%$, typical of CTL-FT synthesis [43], and maximum carbon efficiency is achieved for 35 wt.\% (36.84\% including pure biomethane or $36.31 \%$ accounting for only liquid biofuels).

On the contrary, the electricity is higher for cases with more diluted aqueous fraction (8682 vs $4030 \mathrm{~kW}$ for 15 and $30 \mathrm{wt} . \%$, respectively), despite the higher electrical power generated in the second turbine when the biofuels production is larger (at high feed concentration), because the flow rate of generated steam increases as the heat released from FT reactor is higher. As the increase in power of the first turbine for more diluted aqueous fraction is almost irrelevant, the higher net electrical power for diluted concentrations is due to the less consumed electrical power because of the reduced gas flow rates to compress in different points throughout the plant.

For 35 wt.\% there is heat surplus in the overall process and no fraction of product gas must be sent to furnace at the PSA1 inlet, even despite the higher energy demand in the DR reactor and the upgrading of FT products (mainly, in distillation columns DEST1 and DEST2). Indeed, this fact limits the outlet pressure of the first turbine, in such a way that 40 bar cannot be set and pressure must be reduced to either 18.5 bar, thus obtaining 
$91 \mathrm{~kg} / \mathrm{h}$ of biomethane and $5441 \mathrm{~kW}$, or to $17.0 \mathrm{bar}$, so no biomethane is produced but more net power electricity is obtained $(5656 \mathrm{~kW})$. Nevertheless, the difference is not significant.

Lastly, the organic feeding concentration also influences on the tuning of $\mathrm{H}_{2} / \mathrm{CO}$ molar ratio at the inlet LTFT because the syngas from SCWR reactor varies in both its flow rate and its composition. This way, for more diluted feed aqueous fractions, the hydrogen flow-rate leaving the FT synthesis loop through the purge is progressively lower and a higher fraction of hydrogen from the PSA1 outlet must be sent for hydrocracking. In addition, reforming gas from SCWR by-passes the HWGS reactor for 15-25 wt.\% cases, because the $\mathrm{CO}$ flow rate, which determines the FT liquid production, is quite low. However, for 30 and 35 wt.\%, a fraction of $\mathrm{CO}$ must be converted into $\mathrm{H}_{2}$ by HWGS reactor, so the by-pass is reduced to 78.0 and $57.5 \%$, respectively. Besides, for these latter two cases no $\mathrm{H}_{2}$-rich stream leaving PSA1 is derived to hydrocracker.

\subsection{Effect of mass flow rate and composition of bio-oil aqueous phase}

Three real mass flow rates of bio-oil aqueous fraction were considered in this paper $(20,60$ and $100 \mathrm{t} / \mathrm{h})$. As expected, biofuels and electricity production vary in a proportional way, and carbon efficiencies with or without refining are the same for three cases. This happens because the plant is not sized, and in fact, the analysis of the effect of mass flow rate on the process performance in a sized plant is more complex. However, these results are interesting since the feed flow rates simulated were real and the plant capacity should be taken into account when applying economy of scale, that is, a larger scale may allow a relative reduction in capital costs, as will be discussed in the next work.

On the other hand, feed composition was changed by varying concentrations of the three most representative compounds (acetic acid, levoglucosan and hydroxyacetone). As can be seen in Table 6, higher carbon efficiencies and biofuels production $(33.06 \%$ and 
$2856 \mathrm{~kg} / \mathrm{h})$ are possible in comparison with other cases $(32.18 \%$ and $2739 \mathrm{~kg} / \mathrm{h}$, for basecase) if hydroxyacetone concentration, instead of acetic acid, is the maximum (5.71 wt.\% in the base case). The reason is the higher number of carbon atoms fed into the process that leads to a higher molar flow-rate of gases (hydrogen, carbon dioxide and methane) generated in SCWR, which are processed through the PSAs and DR reactor, where $\mathrm{H}_{2}$ and CO production is increased and, hence, syngas molar flow-rate fed into the FT reactor is higher. Electricity production and cogeneration water values are similar with respect to those for the base-case (5618 kW and $325 \mathrm{t} / \mathrm{h}$ vs $5724 \mathrm{~kW}$ and $314 \mathrm{t} / \mathrm{h}$ ).

On the other hand, another possible aqueous fraction with the model compounds, previously studied in an experimental way [42], was simulated: $10-5-5-5 \mathrm{wt} . \%$ of acetic acid, hydroxyacetone, 1-butanol and levoglucosan (or glucose), respectively. Regarding the base-case, similar results were obtained in biofuels and electricity production, although slightly higher biofuels production was obtained for the case in which levoglucosan was fed into the process (Table 6).

\subsection{Effect of the temperature of the LTFT reactor}

When increasing the temperature in LTFT (from $220^{\circ} \mathrm{C}$ to 230 and $240{ }^{\circ} \mathrm{C}$ ), $\mathrm{CO}$ conversion per pass increases (assuming 60 and $70 \%$, respectively, as reported $[4,45$, 46]) and, consequently, carbon efficiency also increases with respect to LTFT synthesis loop (carbon efficiency without refining). However, overall carbon efficiency (accounting for the FT product refining and upgrading) gradually decreases from 32.18 $\%$ (base-case) to 31.38 and $30.19 \%$ for 230 and $240{ }^{\circ} \mathrm{C}$, respectively (Figure 4). The reason is that chain growth probability decreases from 0.900 (base-case) to 0.870 (230 ${ }^{\circ} \mathrm{C}$ ) and $0.839\left(240^{\circ} \mathrm{C}\right)$, so heavier hydrocarbon (wax and diesel) production decreases while light hydrocarbon (tail gas and gasoline) production increases. As a middle cut, jet fuel production decreases very slightly with temperature $(898,886$ and $857 \mathrm{~kg} / \mathrm{h}$ for 220 , 
230 and $240{ }^{\circ} \mathrm{C}$, respectively). Besides, as temperature increases, cooling water flow rate increases and electricity production slightly decreases (Figures 5-7), thus concluding that the increase of temperature in LTFT reactor is not beneficial.

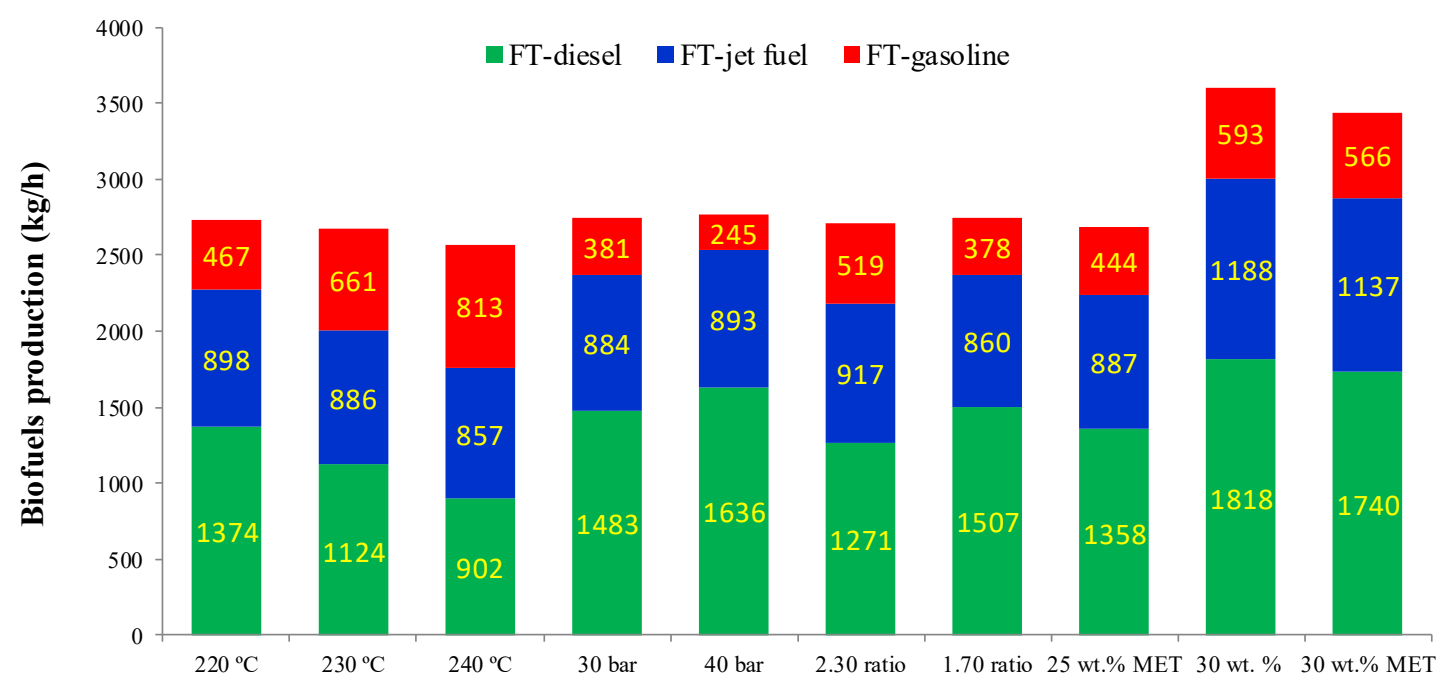

Base case: $220^{\circ} \mathrm{C}, 20 \mathrm{bar}, 2.0$ ratio, $25 \mathrm{wt} \%$; for any case, an operating parameter is changed. MET: similar to base case but in the alternative of burning methane instead of a fraction of product gas These notes must be also applied to Figures 5-7

Figure 4. Biofuels production $(\mathrm{kg} / \mathrm{h})$ for base case/case 3 ( $25 \mathrm{wt}$. \%), FT temperature of 230-240 ${ }^{\circ} \mathrm{C}$, FT pressure of 30-40 bar and FT inlet $\mathrm{H}_{2} / \mathrm{CO}$ molar ratio of 2.30-1.70, as well as case 2 (30 wt. $\%)$ and methane derived to furnace (25-30 wt. \%).

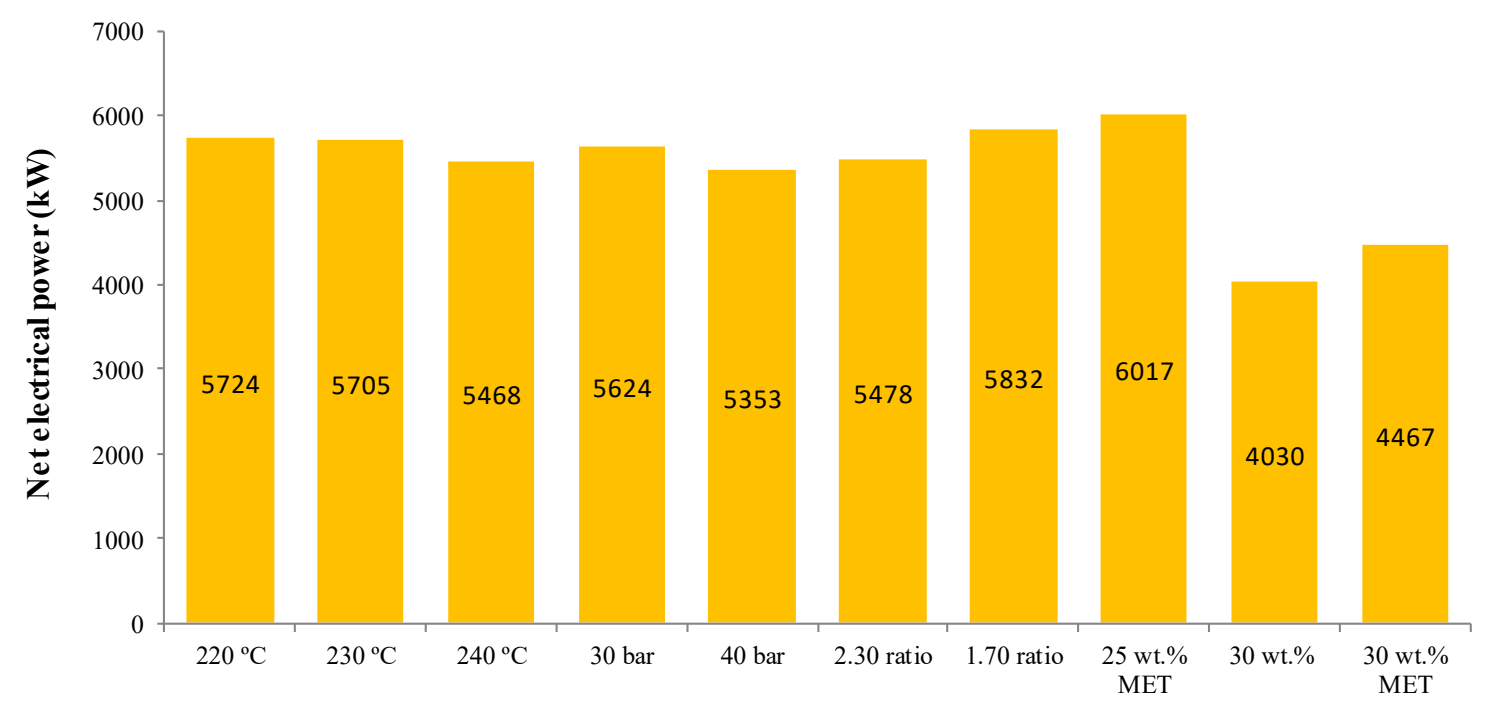

Figure 5. Net electricity production $(\mathrm{kg} / \mathrm{h})$ for base case/case 3 (25 wt. \%), FT temperature of 230$240{ }^{\circ} \mathrm{C}$, FT pressure of $30-40$ bar and FT inlet $\mathrm{H}_{2} / \mathrm{CO}$ molar ratio of $2.30-1.70$, as well as case 2 (30 wt. \%) and methane derived to furnace (25-30 wt. \%). 


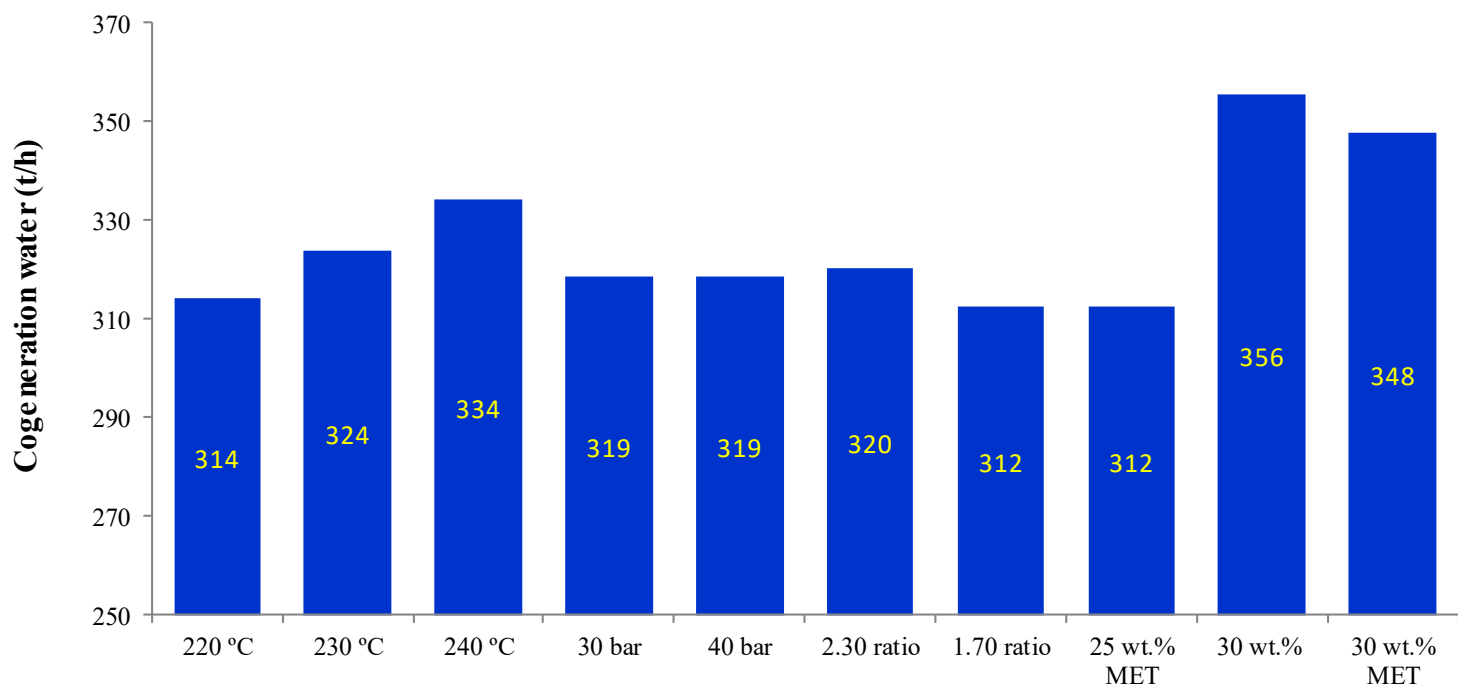

Figure 6. Cogeneration water $(\mathrm{kg} / \mathrm{h})$ for base case/case 3 (25 wt. \%), FT temperature of 230-240 ${ }^{\circ} \mathrm{C}$, FT pressure of 30-40 bar and FT inlet $\mathrm{H}_{2} / \mathrm{CO}$ molar ratio of 2.30-1.70, as well as case 2 (30 wt. \%) and methane derived to furnace (25-30 wt. \%).

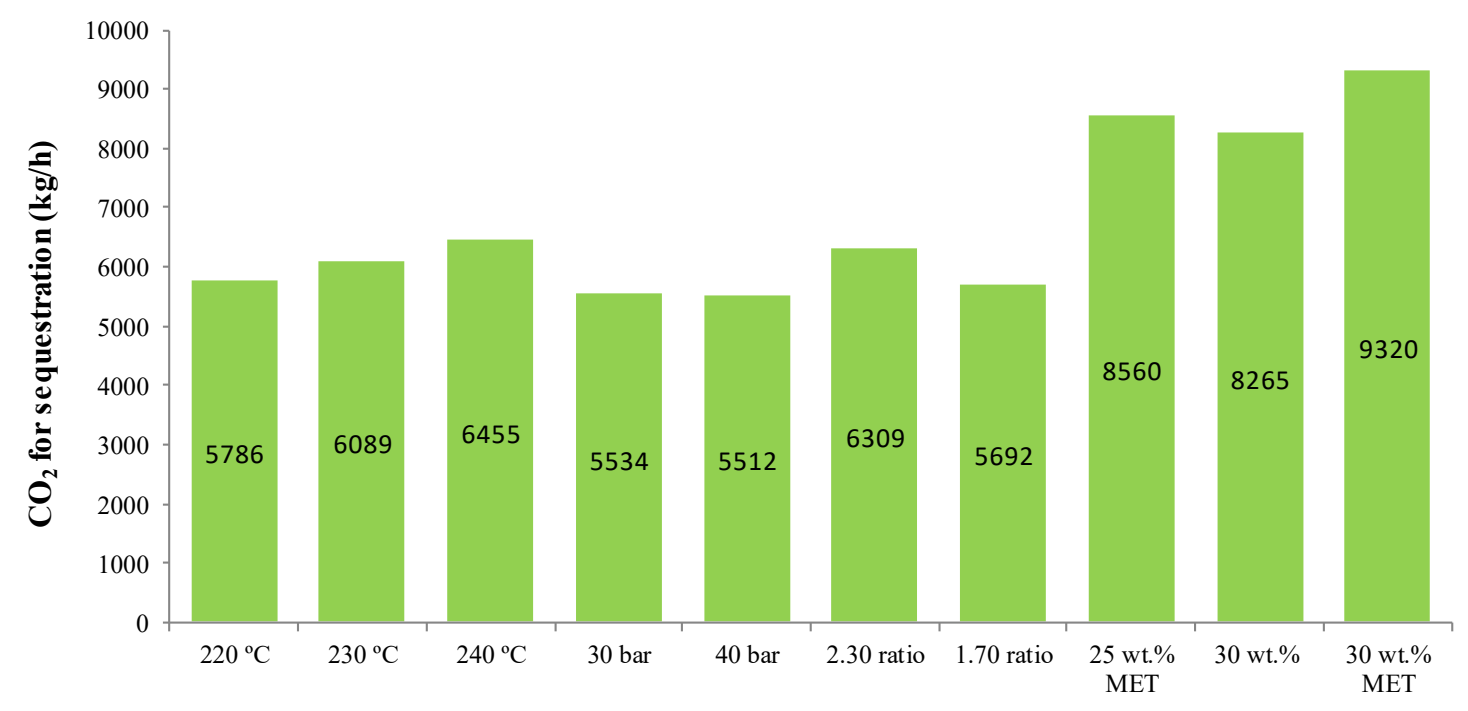

Figure 7. $\mathrm{CO}_{2}$ for sequestration $(\mathrm{kg} / \mathrm{h})$ for base case/case 3 (25 wt. \%), FT temperature of 230$240{ }^{\circ} \mathrm{C}$, FT pressure of 30-40 bar and FT inlet $\mathrm{H}_{2} / \mathrm{CO}$ molar ratio of $2.30-1.70$, as well as case 2 (30 wt. \%) and methane derived to furnace (25-30 wt. \%).

\subsection{Effect of the pressure of the LTFT reactor}

The increase in the LTFT pressure involves higher partial pressures of $\mathrm{H}_{2}$ and $\mathrm{CO}$, and, hence, an increase in the $\mathrm{CO}$ conversion per pass, which were estimated using Arrhenius kinetics, and orders of reaction for $\mathrm{H}_{2}$ and $\mathrm{CO}$ in the rate equation of $\mathrm{CO}$ 
consumption (+3/4 and -1/4, respectively) from Zennaro et al. (2000) [47] and Ma et al. (2014) [48]. Thus, the CO conversion per pass were 50, 54 and $57 \%$ for 20,30 and 40 bar, respectively. On the other hand, and as above mentioned, since Eq. (1) does not provide a relationship between pressure and $\alpha$-values, these were taken from literature [23], obtaining 0.918 and 0.936 for 30 and 40 bar, which leads to a higher wax and diesel productions (1483 and $1636 \mathrm{~kg} / \mathrm{h}$ at 30 and $40 \mathrm{bar}$, respectively, versus $1374 \mathrm{~kg} / \mathrm{h} \mathrm{FT-}$ diesel at 20 bar, as shown in Figure 4). Therefore, unlike for the temperature, an increase in the LTFT pressure leads to a higher liquid selectivity, and the chain growth probability increases. Carbon efficiency with refining increases slightly with pressure $(32.18 \%$ for base-case versus 32.28 and 32.47 for 30 and 40 bar, respectively), since more liquid biofuels are produced in LTFT. However, lower carbon efficiencies without refining (relative to the LTFT synthesis loop) were obtained, due to lower molar flow-rates of light hydrocarbons are produced in LTFT and, in consequence, a higher fraction of product gas must be sent to furnace. On the other hand, net electrical power and cogeneration water present similar results for all cases (Figures 5 and $\mathbf{6}$ ).

\subsection{Effect of the $\mathrm{H}_{2} / \mathrm{CO}$ molar ratio at the inlet of the LTFT reactor}

When $\mathrm{H}_{2} / \mathrm{CO}$ molar ratio increases in the stream entering the LTFT reactor, the equilibrium reaction between $\mathrm{CO}$ and $\mathrm{H}_{2}$ is shifted to the products, thus increasing the CO conversion per pass. Values of $52.0 \%$ and $47.5 \%$ for $\mathrm{CO}$ conversion per pass were obtained (as for pressure sensitivity analysis) for 2.30 and $1.70 \mathrm{H}_{2} / \mathrm{CO}$ molar ratio. However, $\alpha$-values computed by Eq. (1) are 0.912 and 0.888 for 1.70 and 2.30 ratio, respectively, so when increasing the $\mathrm{H}_{2} / \mathrm{CO}$ ratio, the light hydrocarbons selectivity increases, thus decreasing the selectivity of liquid hydrocarbons. Using a ratio value of 2.30, more $\mathrm{H}_{2}$ is needed and, consequently, more $\mathrm{CO}$ coming from SCWR must be converted into $\mathrm{H}_{2}$ by HWGS. However, the fraction of product gas upstream from the 
PSA1 derived to furnace is lower since the higher $\mathrm{H}_{2}$ content and, hence, the higher chemical energy. Thus, $\mathrm{CO}$ entering the FT reactor increases as the $\mathrm{H}_{2} / \mathrm{CO}$ molar ratio increases, and carbon efficiency without refining (in LTFT synthesis loop) is higher. Nevertheless, overall carbon efficiency (with refining) decreases with $\mathrm{H}_{2} / \mathrm{CO}$ molar ratio increases (31.82 for 2.3 ratio versus $32.29 \%$ for 1.7 ratio, as illustrated in Figure 4), because more light hydrocarbons $\left(\mathrm{C}_{2}-\mathrm{C}_{4}\right)$ are produced in LTFT synthesis and after sent to furnace from distillation section. This reduces even more the fraction of product gas derived to furnace before entering the PSA1 unit. Likewise, lower net electrical power is obtained as the $\mathrm{H}_{2} / \mathrm{CO}$ molar ratio increases $(5478 \mathrm{~kW}$ for 2.3 ratio vs. $5832 \mathrm{~kW}$ for 1.7 ratio, as depicted in Figure 5), due to the higher fraction of product gas processed in both DR reactor and FT reactor, which involves higher power compression consumptions.

\subsection{Optimal conditions for maximum biofuel and electricity production}

After analyzing the results from sensitivity analysis, optimal conditions that maximize biofuels production (FT-diesel, FT-jet fuel and FT-gasoline) and provide the maximum net electrical power, accordingly to the biofuels production, corresponds to maximum aqueous phase concentration $(35 \mathrm{wt} . \%)$, minimum LTFT temperature $\left(220^{\circ} \mathrm{C}\right)$, maximum LTFT pressure (40 bar) and minimum $\mathrm{H}_{2} / \mathrm{CO}$ ratio in LTFT reactor (1.70), within the studied operating window.

\subsection{Comparison with other published results}

A comparison with results from other studies was performed (Table 7) in terms of thermal energy efficiency, defined by Eq. (5) accounting for the LHV (lower heat value) of all the FT liquids after refining, or overall energy efficiency that also considers the net electrical power, $\dot{W}_{n e t}$, by Eq. (6), with respect to the energy content in the feed compounds: 
Thermal energy efficiency: $\quad \eta_{\text {Th-energy }}=\frac{\sum_{i} \dot{m}_{\text {Biofuel-i }} L H V_{\text {Biofuel-i }}}{\sum_{j} \dot{m}_{\text {Feed-j }} L H V_{\text {Feed-j }}}$

Overall energy efficiency: $\quad \eta_{\text {Ov-energy }}=\frac{\dot{W}_{\text {net }}+\sum_{i} \dot{m}_{\text {Biofuel-i }} L H V_{\text {Biofuel }-i}}{\sum_{j} \dot{m}_{\text {Feed }-j} L H V_{\text {Feed-j }}}$

Table 7. Comparison with results of other studies

\section{Sensitivity analysis by varying aqueous fraction of bio-oil:}

60 t/h; LTFT conditions: $220{ }^{\circ} \mathrm{C}, 20$ bar, $\mathrm{H}_{2} / \mathrm{CO}$ of 2.0 and $50 \% \mathrm{CO}$ conversion per pass

\begin{tabular}{|l|c|c|c|c|c|c|}
\hline & 15 wt. \% & 20 wt. \% & 25 wt. \% & 30 wt. \% & $\begin{array}{c}35 \text { wt. \% } \\
(17.0 \text { bar })\end{array}$ & $\begin{array}{c}35 \text { wt. \% } \\
(18.5 \text { bar })\end{array}$ \\
\hline Overall energy efficiency (\%) & 34.77 & 47.75 & 55.10 & 56.24 & 58.76 & 59.38 \\
\hline Thermal energy efficiency (\%) & 14.39 & 34.99 & 47.02 & 51.51 & 53.07 & 53.95 \\
\hline Thermal liquid biofuel efficiency (\%) & 14.39 & 34.99 & 47.02 & 51.51 & 53.07 & 53.07 \\
\hline
\end{tabular}

Sensitivity analysis at $60 \mathrm{t} / \mathrm{h}$ and $25 w t . \%$ (base case), by varying:

LTFT temperature $\left(230-240{ }^{\circ} \mathrm{C}\right)$, pressure (30-40 bar) and $\mathrm{H}_{2} / \mathrm{CO}$ molar ratio (1.70-2.30)

\begin{tabular}{|l|c|c|c|c|c|c|}
\hline & $230^{\circ} \mathrm{C}$ & $240^{\circ} \mathrm{C}$ & 30 bar & 40 bar & 1.70 & 2.30 \\
\hline Overall energy efficiency (\%) & 53.97 & 51.96 & 55.00 & 55.45 & 55.33 & 54.25 \\
\hline Thermal energy efficiency (\%) & 45.94 & 44.26 & 47.08 & 47.23 & 47.12 & 46.53 \\
\hline
\end{tabular}

Sensitivity analysis by varying individual compounds of aqueous fraction of bio-oil and design:

60 t/h; 25 wt. \%; LTFT conditions: $220{ }^{\circ} \mathrm{C} ; 20$ bar; $\mathrm{H}_{2} / \mathrm{CO}=2.0$ and $\mathrm{CO}$ conversion per pass: $50 \%$

\begin{tabular}{|l|c|c|c|c|c|c|}
\hline & Case 4 & Case 5 & Case 8 & Case 9 & $\begin{array}{c}25 \text { wt. \% } \\
\text { MET }(*)\end{array}$ & $\begin{array}{c}30 \text { wt. \% } \\
\text { MET (*). }\end{array}$ \\
\hline Overall energy efficiency (\%) & 55.13 & 58.58 & 57.39 & 48.97 & 54.66 & 54.94 \\
\hline Thermal energy efficiency (\%) & 47.47 & 50.17 & 48.24 & 41.63 & 46.18 & 49.29 \\
\hline
\end{tabular}

(*): 25 and 30 wt. \% MET: cases where methane is derived to furnace when total aqueous phase is 25 wt. $\%$ and 30 wt. \% respectively

In this study, overall energy efficiency varied mainly with the aqueous fraction concentration, so the minimum value was $34.77 \%$ (for $15 \mathrm{wt} . \%$ ) and the maximum was $59.38 \%$ (for 35 wt.\%). Likewise, regarding the base case (55.10 \%), similar results were obtained (from 54.25 to $55.45 \%$ ) as LTFT pressure and $\mathrm{H}_{2} / \mathrm{CO}$ ratio varied, but overall energy efficiencies were lower when LTFT temperature increased to $240{ }^{\circ} \mathrm{C}(51.96 \%)$.

In a previous study by Siew et al. [6], using an aqueous solution of acetic acid, acetol and guaiacol (69.85 wt.\%), and operating the FT reactor at $240{ }^{\circ} \mathrm{C}$ and 25 bar, maximum 
overall efficiency was $58.2 \%$, even considering all $\mathrm{C}_{5+}$ compounds in the computation of energy efficiency of the process and the recovery of the low-grade heat into useful byproducts such as hot water. In another study by Selvatico et al. [2], overall energy efficiency was $43.7 \%$ based on a clean syngas, using $220^{\circ} \mathrm{C}, 25$ bar and a $\mathrm{H}_{2} / \mathrm{CO}$ molar ratio of 2.0 as LTFT operating conditions. However, they did not take advantage of the generated steam from LTFT exothermic reactions and $\mathrm{CO}_{2}$ was not converted into $\mathrm{H}_{2}$ and CO to increase the syngas mass-flow. Likewise, Xiang et al. [49] proposed a process that integrated coal-to-syngas and syngas-to-olefins, where overall energy efficiency was 33.9-48.4\%. These researchers did not try to diminish $\mathrm{CO}_{2}$. Similarly, Sudiro et al. [3] achieved an overall energy efficiency of $56.4 \%$, with synthetic fuels from two different feedstocks (coal and natural gas), operating the LTFT reactor at $240{ }^{\circ} \mathrm{C}$ and 15 bar. Finally, Leibbrandt et al. [50] obtained an overall energy efficiency of $59 \%$ in the production of liquid FT and electricity by biomass gasification (at 40 bar and $1700 \mathrm{~K}$ ), where the LTFT reactor conditions were $260{ }^{\circ} \mathrm{C}, 23.2$ bar and $2.0 \mathrm{H}_{2} / \mathrm{CO}$ molar ratio.

Regarding the different liquid biofuels cuts (gasoline, diesel and jet fuel), diesel and jet fuel correspond to distillate stream in other studies, while gasoline is sometimes referred as naphta. Thus, Selvatico et al. [2] obtained component fractions of 11.49-17.96 $\%$ for naphta $\left(\mathrm{C}_{5}-\mathrm{C}_{10}\right), 71.25-77.86 \%\left(\mathrm{C}_{11}-\mathrm{C}_{22}\right)$ for distillate and $11.05-11.40 \%\left(\mathrm{C}_{22+}\right)$ for wax. The rest was $\mathrm{C}_{1}-\mathrm{C}_{4}$. By considering the same cuts, similar results were obtained in our study although somewhat higher for distillate (78.01\%) and naphta (21.99\%). In another publication, Er-rbib et al. [26] concluded that their process could produce synthetic fuels composed of $72 \%$ of diesel $\left(\mathrm{C}_{12}-\mathrm{C}_{18}\right), 26 \%$ of gasoline $\left(\mathrm{C}_{5}-\mathrm{C}_{11}\right)$ and $2 \%$ of $\mathrm{C}_{2}-\mathrm{C}_{4}$. By considering these cuts, very similar results were obtained when the LTFT reactor operates at 30 bar (70.48 \% for diesel and $29.52 \%$ for gasoline). 


\section{Conclusions}

A new and comprehensive energy self-sufficient process aimed at maximizing biofuels and net power production from low-temperature Fischer-Tropsch (LTFT) synthesis using syngas obtained by supercritical water reforming (SCWR) of bio-oil aqueous phase was proposed and studied. By this process, a waste is valorized, and the produced $\mathrm{CO}_{2}$ is separated with a high purity for sequestration, which gives added value to the proposed process. Optimal conditions were found by analyzing the effect of different operating variables regarding the bio-oil aqueous phase (concentration, composition and mass-flow in the feeding stream) and the operation of LTFT reactor (temperature, pressure and $\mathrm{H}_{2} / \mathrm{CO}$ molar ratio) on the process performance. This was assessed by carbon efficiencies with and without refining, as well as energy efficiency that includes net electrical power. The results show that biofuels production (FT-diesel, FT-jet fuel and FT-gasoline) is maximized at maximum aqueous phase concentration (35 wt.\%), minimum LTFT temperature $\left(220^{\circ} \mathrm{C}\right)$, maximum LTFT pressure (40 bar) and minimum $\mathrm{H}_{2} / \mathrm{CO}$ molar ratio in LTFT reactor (1.70), within the studied operating window. Under these conditions, for a mass flow of aqueous phase of $60 \mathrm{t} / \mathrm{h}$, biofuels production was $4596 \mathrm{~kg} / \mathrm{h}(2804 \mathrm{~kg} / \mathrm{h}$ FT-diesel, $1491 \mathrm{~kg} / \mathrm{h}$ FT-jet fuel and $301 \mathrm{~kg} / \mathrm{h}$ FTgasoline), a carbon efficiency with refining of $38.53 \%$ was achieved (without refining, it was $43.50 \%$ ), and net electrical power was $5297 \mathrm{kWe}$. In addition, the separated $\mathrm{CO}_{2}$ for sequestration is $0.50 \mathrm{~kg} / \mathrm{kg}$ organic feeding and $17.5 \mathrm{~kg}$ hot water $/ \mathrm{kg}$ organic feeding, which gives added value to the proposed process.

\section{Appendix A. Thermal energy integration}

Figure 2 includes the energy integration through heat exchangers located in the process to improve the energy use. Table A1 shows the main specifications of heat exchangers and other auxiliary equipment. The strategy followed for heat exchangers 
network is that streams close to each other at high thermal levels are the first to contact each other (the high-temperature hot streams warm up the high-temperature cold streams), and streams at low thermal levels are the last to contact each other (the lowtemperature hot streams heat the low-temperature cold streams). SCWR and DR are the central points, where maximum temperatures are set. Although there could be more alternative flow sheets for this process due to possible redistributions of heat exchangers, the proposed flow-sheet provides the best heat integration performance, because minimizes the use of external utilities and maximizes heat flows into the system.

The heat required to maintain endothermic reactions in DR reactor is transferred from the hot flue gas coming from the furnace. Similarly, a heat stream exits from furnace towards SCWR to heat the feed of this reactor to $800{ }^{\circ} \mathrm{C}$ and to maintain the endothermic chemical reactions.

Likewise, the heat of highly exothermic FT reactions (about $150 \mathrm{~kJ}$ per mole of CO converted [2]), must be efficiently released to avoid catalyst deactivation via sintering and formation of methane, which is undesirable since selectivity of preferred products would decrease. In this study, LTFT is equipped with an evaporator where cooling water, coming from the heat exchanger located at the outlet of the FT reactor to cool down the FT products, enters as liquid at $212^{\circ} \mathrm{C}$ and 20 bar and exits but as saturated steam at the same conditions. A fraction of this steam is send to preheat the inlet FT stream and the rest is expanded (to 1 bar and $99{ }^{\circ} \mathrm{C}$ ) in a steam turbine (TURB2) to produce electricity.

In a similar way, the feed to DR reactor is heated to $600{ }^{\circ} \mathrm{C}$ by two heat exchangers. Similarly, the process stream must be heated to the specified operating temperature of LTFT by two heat exchangers. Afterwards, streams of flue gas and from the DR products transfer heat to the kettles of distillation columns DEST1 and DEST2. Lastly, all cooling water streams (at atmosphere pressure and $99^{\circ} \mathrm{C}$ ) are collected, so the energy scheme also 
involves cogeneration (e.g., hot water for district heating) thus increasing the overall

efficiency of the process. Finally, the flue gas from furnace is cooled to about $120{ }^{\circ} \mathrm{C}$

before emitting it to the atmosphere.

Table A1. Specifications of the heat exchangers and other auxiliary equipment.

\begin{tabular}{|c|c|c|}
\hline Code & Equipment & Specifications \\
\hline HE01 & Heat exchanger & Cold stream outlet temperature: variable \\
\hline HE02 & Heat exchanger & Hot stream outlet temperature: $700^{\circ} \mathrm{C}$ \\
\hline HE03 & Heat exchanger & Hot stream outlet temperature: $350^{\circ} \mathrm{C}$ \\
\hline HE04 & Heat exchanger & Cold stream outlet temperature: variable \\
\hline HE05 & Heat exchanger & Hot stream outlet temperature: $35^{\circ} \mathrm{C}$ \\
\hline HE06 & Heat exchanger & Cold stream outlet temperature: variable \\
\hline HE07 & Heat exchanger & Cold stream outlet temperature: $600^{\circ} \mathrm{C}$ \\
\hline HE08 & Heat exchanger & Cold stream outlet temperature: $360^{\circ} \mathrm{C}$ \\
\hline HE09 & Heat exchanger & Cold stream outlet temperature: variable \\
\hline HE10 & Heat exchanger & Hot stream outlet temperature: $35^{\circ} \mathrm{C}$ \\
\hline HE11 & Heat exchanger & Cold stream outlet temperature: variable $\left(210-215^{\circ} \mathrm{C}\right)$ \\
\hline HE12 & Heat exchanger & Cold stream outlet temperature: variable $\left(220-240^{\circ} \mathrm{C}\right)$ \\
\hline HE13 & Heat exchanger & Hot stream outlet temperature: $35^{\circ} \mathrm{C}$ \\
\hline HE14 & Heat exchanger & Hot stream outlet temperature: $35^{\circ} \mathrm{C}$ \\
\hline HE15 & Heat exchanger & Hot stream outlet temperature: $360^{\circ} \mathrm{C}$ \\
\hline HE16 & Heat exchanger & Cold stream outlet temperature: $98^{\circ} \mathrm{C}$ \\
\hline HE17 & Heat exchanger & Cold stream outlet temperature: variable \\
\hline HE18 & Heat exchanger & Hot stream outlet temperature: $99^{\circ} \mathrm{C}$ \\
\hline $\mathrm{C} 1$ & Heat exchanger & Heat flow for endothermic heat reaction in DRYREF \\
\hline $\mathrm{C} 2$ & Heat exchanger & Sink of the heat flow coming from the condenser of the DEST3 \\
\hline $\mathrm{C} 3$ & Heat exchanger & Sink of the heat flow coming from the condenser of the DEST1 \\
\hline $\mathrm{C} 4$ & Heat exchanger & Sink of the heat flow coming from the condenser of the DEST2 \\
\hline $\mathrm{C} 5$ & Heat exchanger & Heat flow from LTFT \\
\hline $\mathrm{H} 1$ & Heat exchanger & Heat flow towards the reboiler of DEST1 \\
\hline $\mathrm{H} 2$ & Heat exchanger & Heat flow towards the reboiler of DEST2 \\
\hline $\mathrm{H} 3$ & Heat exchanger & Heat flow towards the reboiler of DEST3 \\
\hline SP1 & Splitter & $\begin{array}{l}\text { Split fraction stream 10: variable (the objective is to achieve the } \\
\text { hydrogen molar flow required to adjust the } \mathrm{H}_{2} / \mathrm{CO} \text { molar ratio). }\end{array}$ \\
\hline SP2 & Splitter & $\begin{array}{l}\text { Split fraction stream 15: variable (aimed at achieving the energy self- } \\
\text { sufficiency constraint). }\end{array}$ \\
\hline SP3 & Splitter & $\begin{array}{l}\text { Split fraction stream 17-H-C: variable on required } \mathrm{H}_{2} \text { for } \\
\text { hydrocracking. }\end{array}$ \\
\hline SP4 & Splitter & $\begin{array}{l}\text { Split fraction stream 46: variable (aimed at maximizing CO total } \\
\text { conversion as much as possible). }\end{array}$ \\
\hline SP5 & Splitter & $\begin{array}{l}\text { Split fraction stream 51-G: variable (with the goal of sending the } \\
\text { required hydrogen to the hydrocracking reactor) }\end{array}$ \\
\hline SP6 & Splitter & $\begin{array}{l}\text { Split fraction stream } \mathrm{CH}_{4}-\mathrm{O} \text { : variable (in some cases, biomethane could } \\
\text { be sold if energy self-sufficiency was achieved) }\end{array}$ \\
\hline SP7 & Splitter & $\begin{array}{l}\text { Split fraction stream } 06 \mathrm{~V} \text { : variable (with the goal of preheating the } \\
\text { LTFT inlet stream, and producing electrical power by the steam turbine } \\
\text { with the rest of steam }(02 \mathrm{~V} \text { stream) }\end{array}$ \\
\hline P3-P4 & $\begin{array}{l}\text { Pumps (streams W4, W5) -not } \\
\text { drawn in Figure 2- }\end{array}$ & Efficiency: $0.75 ;$ Outlet pressure: 20 bar \\
\hline P5-P7 & $\begin{array}{l}\text { Pumps (streams W1, W2, W3) -not } \\
\text { drawn in Figure 2- }\end{array}$ & Efficiency: 0.7; Outlet pressure: 1.1 bar \\
\hline
\end{tabular}




\section{Appendix B. Alternative configurations}

Different configurations of the process were also studied, analyzed and compared with the proposed flowsheet. First, an alternative system consists of passing the entire product gas through the first PSA system and sending a fraction of the methane and carbon dioxide from PSA2 directly to the PSA3 unit, so pure methane is derived to furnace and pure carbon dioxide is sequestered. This way, less $\mathrm{CH}_{4}$ and $\mathrm{CO}_{2}$ are fed into DR reactor to produce $\mathrm{H}_{2}$ and $\mathrm{CO}$, and the flow rate at the inlet of the FT synthesis loop is reduced. A sensitivity analysis was carried out for 25 and $30 \mathrm{wt} . \%$, and the results are shown in Figure 4-7. For 25 wt. \% similar results were obtained in both options (combustion of pure $\mathrm{CH}_{4}$ versus a fraction of product gas before entering the PSA1 unit), although the option in which a fraction of reforming gas is withdrawn before entering the PSA1 unit was chosen because higher biofuels production is obtained and, conceptually, it is better to burn a product gas as soon as possible, before further treatments. However, both net electricity and $\mathrm{CO}_{2}$ flow rate for sequestration present higher values for the alternative option. Besides, the results also affect the equipment sizes, because lower mass flow rates are treated in PSA1, COMP1, PSA2 and PSA3 for the chosen option, but higher amounts of gases will pass through COMP2, COMP3, PSA1A, PSA2A and the DR reactor. Both options will be further studied in a future techno-economic analysis. For 30 wt. $\%$, the difference between biofuels production is higher than for $25 \mathrm{wt} . \%$, where the chosen option provides $3599 \mathrm{~kg} / \mathrm{h}$ of biofuels versus $3443 \mathrm{~kg} / \mathrm{h}$ in the alternative option

(Figure 4), while net power and pure carbon dioxide (Figures 5, 7) are higher for this latter option (4467 kW and $9320 \mathrm{~kg} / \mathrm{h} \mathrm{CO} 2$ versus $4030 \mathrm{~kW}$ and $8265 \mathrm{~kg} / \mathrm{h} \mathrm{CO}$ ).

On the other hand, the sale of low-pressure steam ( 8 bar) was considered as an alternative to expand the steam in the second turbine to 1 bar, which could be interesting if the process was located close to other industrial plants demanding steam as utility. For 
this case, outlet pressure of second turbine is specified in 8 bar, and lower cooling water flow-rate is necessary, which is an environmental advantage. However, electrical power in second turbine is quite reduced and total benefits could be likely lower, so this was not the chosen option. This option might be more interesting for higher total organic concentrations in the feed stream $(19460$ and $9300 \mathrm{~kg} / \mathrm{h}$ of steam are produced for 30 and 20 wt.\%, respectively), although the chosen option allows maximizing the net electrical power (for $30 \mathrm{wt} . \%, 2524 \mathrm{~kW}$ if saturated steam is considered versus $4030 \mathrm{~kW}$ when this potential utility is not produced).

\section{References}

[1] Zwart RWR, Boerritger H. High efficiency co-production of synthetic natural gas (SNG) and Fischer-Tropsch (FT) transportation fuels from biomass. Energ Fuel 2005;19:591-7.

[2] Selvatico D, Lanzini A, Santarelli M. Low temperature Fischer-Tropsch fuels from syngas: Kinetic modeling and process simulation of different plant configurations. Fuel 2016;186:544-60.

[3] Sudiro M, Bertucco A. Production of synthetic gasoline and diesel fuel by alternative processes using natural gas and coal: Process simulation and optimization. Energy 2009;34:2206-14.

[4] Saeidi S, Nikoo MK, Mirvakili A, Bahrani S, Amin NAS, Rahimpour MR. Recent advances in reactors for low-temperature Fischer-Tropsch synthesis: process intensification perspective. Rev Chem Eng 2015;31:209-38

[5] van der Laan GP. Kinetics, selectivity and scale up of the Fischer-Tropsch synthesis. Dissertation, University of Groningen, 1999.

[6] Siew K, Sadhuklan J. Techno-economic performance analysis of bio-oil based FischerTropsch and CHP synthesis platform. Biomass Bioenerg 2011;35:3218-34.

[7] Gutiérrez Ortiz FJ, Ollero P, Serrera A, Sanz A. Thermodynamic study of the supercritical water reforming of glycerol. Int J Hydrogen Energy 2011;36:8994-9013. 
[8] Gutiérrez Ortiz FJ, Serrera A, Galera S, Ollero P. Experimental study of the supercritical water reforming of glycerol without the addition of a catalyst. Energy 2013;56:193-206.

[9] Gutiérrez Ortiz FJ, Campanario FJ, Aguilera PG, Ollero P. Hydrogen production from supercritical water reforming of glycerol over nickel catalysts. Energy 2015;84:634-42.

[10] Gutiérrez Ortiz FJ, Campanario FJ, Aguilera PG, Ollero P. Supercritical water reforming of glycerol: Performance of $\mathrm{Ru}$ and $\mathrm{Ni}$ catalysts on $\mathrm{Al}_{2} \mathrm{O}_{3}$ support. Energy 2016;96:561-8.

[11] Gutiérrez Ortiz FJ, Campanario FJ, Ollero P. Turnover rates for the supercritical water reforming of glycerol on supported Ni and Ru catalysts. Fuel 2016;180:417-23.

[12] Bouchy C, Hastoy G, Guillon E, Martens JA. Fischer-Tropsch wax upgrading via hydrocracking and selective hydroisomerization. Oil Gas Sci Technol 2009;64:91-112.

[13] Sie ST, Senden MMG, Van Wechem HMH. Conversion of natural gas to transportation fuels via the shell middle distillate synthesis process (SMDS). Catal Today 1991;8:371-94.

[14] Zhu M, Wachs IE. Determining number of active sites and TOF for the high-temperature water gas shift reaction by iron oxide based catalysts. ACS Catal 2016;6.

[15] Gutiérrez Ortiz FJ, Serrera A, Galera S, Ollero P. Methanol synthesis from syngas obtained by supercritical water reforming of glycerol. Fuel 2013;105:739-51.

[16] Schakel W, Oreggioni G, Singh B, Strømman A, Ramírez A. Assessing the technoenvironmental performance of $\mathrm{CO}_{2}$ utilization via dry reforming of methane for the production of dimethyl ether. $\mathrm{J} \mathrm{CO}_{2}$ Util 2016;16:138-49.

[17] Ermaloev IS, Ermaloev VS, Mordkovich VZ. Efficiency of gas-to-liquids technology with different synthesis gas production methods. Ind Eng Chem Res 2014;53:2758-63.

[18] Gopaul SG, Dutta A. Dry reforming of multiple biogas types for syngas production simulated using Aspen Plus: The use of partial oxidation and hydrogen combustion to achieve thermo-neutrality. Int J Hydrogen Energy 2015;40:6307-18.

[19] Zhang J, Webley PA. Cycle development and design $\mathrm{CO}_{2}$ capture from flue gas by vacuum swing adsorption. Environ Sci Technol 2008;42:563-9. 
[20] Song HS, Ramkrishna D, Trinh S, Wright H. Operating strategies for Fischer-Tropsch reactors: a model-directed study. Kor J Chem Eng 2004;21:308-17.

[21] Todic B, Bhatelia T, Froment GF, Ma W, Jacobs G, Davis BH, Bukur DB. Kinetic model of Fischer-Tropsch synthesis in a slurry reactor on $\mathrm{Co}-\mathrm{Re} / \mathrm{Al}_{2} \mathrm{O}_{3}$ catalyst. Ind Eng Chem Res 2013;52:669-79.

[22] Schulz H, Claeys M. Kinetic modelling of Fischer-Tropsch product distributions. Appl Catal 1990;186:91-107.

[23] Van Berge PJ. Cobalt as an alternative Fischer-Tropsch catalyst to iron for the production of middle distillates. Stud Surf Sci Catal 1997;107:207-12.

[24] Kraum M. Fischer-Tropsch synthesis on supported cobalt-based catalysts: influence of various preparation methods and supports on catalyst activity and chain growth probability. Dissertation, Ruhr-Universität Bochum, 1999.

[25] Iliuta I, Larachi F, Anfray J, Dromard N, Schweich D. Multicomponent multicompartment model for Fischer-Tropsch SCBR. AIChE J 2007;53:2062-83.

[26] Er-rbib H, Bouallou C, Werkoff F. Production of synthetic gasoline and diesel fuel from dry reforming of methane. Energy Procedia 2012;29:156-65.

[27] Pellegrini L, Locatelli S, Rasella S, Bonomi S, Calemma V. Modeling of FischerTropsch products hydrocracking. Chem Eng Science 2004;59:4781-7.

[28] Sun C, Zhan T, Pfeifer P, Dittmeyer R. Influence of Fischer-Tropsch synthesis (FTS) and hydrocracking (HC) conditions on the product distribution of an integrated FTS-HC process. Chem Eng J 2017;310:272-81.

[29] Regali F. Hydroconversion of model Fischer-Tropsch wax over noble metal/silicaalumina catalysts. Dissertation, KTH Royal Institute of Technology in Stockholm, 2013. [30] Brosius R, Fletcher J. Hydrocracking under Fischer-Tropsch conditions; the effect of CO on the mass transfer resistance by metal clusters. J Catal 2014;317:318-25. 
[31] Froment GF. Kinetics of the hydroisomerization and hydrocracking of paraffins on a platinum containing bifunctional Y-zeolite. Catal Today 1987;1:455-73.

[32] Tiong Sie S. Acid-catalyzed cracking of paraffinic hydrocarbons. 3. Evidence for the protonated cyclopropane mechanism from hydrocracking/hydroisomerization experiments. Ind Eng Chem Res 1993;32:403-8.

[33] Kumar H. Mechanistic Kinetic Modeling of the Hydrocracking of Complex Feedstocks. Dissertation, Indian Institute of Technology \& Texas University 2006.

[34] Oasmaa A, Meier D. Norms and standards for fast pyrolysis liquids 1. Round robin test. J Anal Appl Pyrolysis 2005;73:323-34.

[35] Marker TL. Opportunities for biorenewables in oil refineries. U.S. Deparment of energy, Office of Energy Efficiency and Renewable Energy, 2005.

[36] Manganaro JL, Lawal A. Economics of Thermochemical Conversion of Crop Residue to Liquid Transportation Fuel. Energ Fuel 2012;26:2442-53.

[37] Farag IH, LaClair CE, Barrett CJ. Technical, Environmental and Economic Feasibility of Bio-Oil in New Hampshire's North Country. Chemical Engineering Dept, University of New Hampshire (UNH), Durham, NH, USA.

[38] Dermibas A. The influence of temperature on the yields of compounds existing in biooils obtained from biomass samples via pyrolysis. Fuel Process Technol 2007;88:591-7.

[39] Yang SI, Wu MS, Wu CY. Application of biomass fast pyrolysis part I: Pyrolysis characteristics and products. Energy 2014;66:162-71.

[40] Balat M, Balat M, Kirtay E, Balat H. Main routes for the thermo-conversion of biomass into fuels and chemicals. Part 1: Pyrolysis systems. Energ Convers Manage 2009;50:314757.

[41] Takahashi K, Satoh H, Satoh T, Kakuchi T, Miura M, Sasaki A, Sasaki M, Kaga H. Formation kinetics of levoglucosan from glucose in high temperature water. Chem Eng $\mathrm{J}$ 2011;153:170-4. 
[42] Gutiérrez Ortiz FJ, Campanario FJ, Ollero P. Supercritical water reforming of model compounds of bio-oil aqueous phase: Acetic acid, acetol, butanol and glucose. Chem Eng $\mathrm{J}$ 2016;298:243-58.

[43] Klerk A. Fischer-Tropsch Refining. 2011 Wiley-VCH Verlag \& Co. KGaA, Boschstr. 12, 69469 Weinheim, Germany.

[44] Hamelinck CN. Outlook for advanced biofuels. Dissertation, Univ. Utrecht, 2004.

[45] Cao C, Hu J, Li S, Wilcox W, Wang Y. Intensified Fischer-Tropsch synthesis process with microchannel catalytic reactors. Catal Today 2009;140:149-56.

[46] Guettel R, Turek T. Comparison of different reactor types for low temperature FischerTropsch synthesis: a simulation study. Chem Eng Sci 2009;64:955-64.

[47] Zennaro R, Tagliabue M, Bartholomew CH. Kinetics of Fischer-Tropsch synthesis on titania-supported cobalt. Catal Today 2000;58:309-19.

[48] Ma W, Jacobs G, Sparks DE, Spicer RL, Davis BH, Klettlinger JLS, Yen CH. FischerTropsch synthesis: kinetics and water effect study over $25 \% \mathrm{Co} / \mathrm{Al}_{2} \mathrm{O}_{3}$ catalysts. Catal Today 2014;228:158-66.

[49] Xiang D, Yang S, Qian Y. Techno-economic analysis and comparison of coal based olefins processes. Energ Convers Manage 2016;110:33-41.

[50] Leibbrandt N, Aboyade A, Knoetze J, Görgens J. Process efficiency of biofuel production via gasification and Fischer-Tropsch synthesis. Fuel 2013;109:484-92.

[51] Zacher AH, Olarte MV, Santosa DM, Elliott DC, Jones SB. A review and perspective of recent bio-oil hydrotreating research. Green Chem, 2014;16:491-515. 